Popovic, T., Kraslawski, A., Barbosa-Póvoa, A., \& Carvalho, A. (2017).

Quantitative indicators for social sustainability assessment of society and product

responsibility aspects in supply chains. Journal of International Studies, 10(4), 9-36.

doi:10.14254/2071-8330.2017/10-4/1

\title{
Quantitative indicators for social sustainability assessment of society and product responsibility aspects in supply chains
}

\author{
Tamara Popovic \\ Industrial Engineering and Management, School of Business and \\ Management, Lappeenranta University of Technology \\ Finland \\ tamara.popovi@@lut.fi
}

\author{
Andrzej Kraslawski \\ Industrial Engineering and Management, School of Business and \\ Management, Lappeenranta University of Technology \\ Finland \\ Faculty of Process and Environmental Engineering, Technical \\ University of Lodz \\ Poland \\ andrzej.kraslawski@lut.fi \\ Ana Barbosa-Póvoa \\ CEG-IST, Instituto Superior Tecnico, University of Lisbon \\ Portugal \\ apovoa@tecnico.ulisboa.pt \\ Ana Carvalho \\ CEG-IST, Instituto Superior Tecnico, University of Lisbon \\ Portugal \\ anacarvalho@tecnico.ulisboa.pt
}

Abstract. Increased pressures from stakeholders have been forcing companies to integrate social sustainability into their businesses. However, lack of information leads to gaps in social sustainability, some of them being also related to difficulties in social sustainability assessment of supply chains often caused by lack of appropriate quantitative indicators to be used. The aim of this paper is, thus, to fill this gap by proposing a set of quantitative social sustainability indicators applicable to various types of supply chains. The indicators proposed here address the most frequently encountered issues of social sustainability. The of International
Studies

(c) Foundation of International

Studies, 2017 (c) CSR, 2017 research resulted in the identification of 24 generic quantitative indicators suitable for the assessment of a supply chain, particularly related to society and product

Received: August, 2017 1st Revision: September, 2017

Accepted: November, 2017

DOI:

10.14254/2071 $8330.2017 / 10-4 / 1$ 
responsibility issues. The indicators are validated through content analysis of 141 sustainability reports from all echelons (upstream, midstream, downstream) of a supply chain. Beyond that, one-way statistical analysis (ANOVA) is performed in order to analyse how echelon levels affect the relevance of these indicators. Content analysis results confirm that issues covered by the indicators are addressed by the companies in their sustainability reports, while ANOVA analysis shows that supply chain echelon level does not influence the relevance of the indicators, making this set of indicators generic and applicable to any supply chain. Therefore, these indicators can be considered as generic and used for the holistic assessment of supply chains.

Keywords: social sustainability, quantitative indicators, supply chain management, performance measurement.

JEL Classification: M14, Q01, Q56

\section{INTRODUCTION}

Spanning from industry to academy, sustainability of supply chains have gained a lot of attention (Varsei \& Polyakovskiy, 2017). This trend is also supported by the pressures of stakeholders who are getting more involved in the process of sustainable development by demanding more transparency along supply chains (Fritz et al., 2017). Fritz et al. (2017) explain that the aforementioned transparency can be achieved by developing methods and indicators for supply chain sustainability assessment. Since sustainability is based on the triple bottom line it is desirable that economic, environmental and social pillars are balanced. In reality, this balance is disrupted, as the main goal for businesses is profit (i.e., economic sustainability) followed by environmental concern (environmental sustainability) (Missimer et al., 2017; Mani et al., 2016). Thus, in order to meet the requirements of sustainable supply chains, businesses should consider the social pillar as well. This would allow "a balanced approach to the decision making processes of supply chain design and management" (Varsei \& Polyakovskiy, 2017; p. 236).

The aforementioned unbalanced situation towards sustainability pillars led to the existence of research gaps in the social sustainability topic. As the main research gaps, one can identify scarcity of information on social sustainability such as the lack of consensus on social impact categories, lack of quantitative social sustainability indicators as well as lack of suitable methods for social sustainability assessment of supply chains (Garcia et al., 2016; Rahdari \& Rostamy, 2015). Therefore, the aim of this paper is to fill these gaps and to propose a set of quantitative social sustainability indicators for the assessment of the whole supply chains.

This paper takes into account the social pillar of sustainability by proposing a quantitative assessment of supply chains, covering a holistic view, which considers the three supply chain echelons - upstream, midstream, and downstream. This work proposes quantitative social sustainability indicators for the endpoint impact categories society and product responsibility. Further, these indicators are validated through conducting the content analysis of 141 sustainability reports. The results are analysed and the influence of the SC's echelons on the importance of the indicators is verified by means of ANOVA statistical analysis. Finally, discussion and research conclusions are provided together with the limitations of this study and directions for future research. 


\section{STATE OF THE ART}

The ongoing trend of increased interests in social issues of supply chains is caused by the growing pressures from government, customers, NGOs and other interested stakeholders (Mani et al., 2016). Consequently, social sustainability is becoming more and more incorporated in the business practice, both on corporate and the supply chain level (Vachon \& Mao, 2008). However one of the main issues arising from the incorporation of social sustainability in supply chains is the assessment of the social sustainability, i.e. lack of consensus on the impacts which should be considered and their quantification (Hutchins \& Southerland, 2008; Beske-Jansen et al., 2015). Indeed, current literature shows that social sustainability in the supply chains has not been well explored and explained (Mani et al., 2015). Hence the assessment of the social performance of the supply chains is aggravated. Especially because of the lack of the measures and indicators that can ensure quantitative assessment of the social sustainability (Ahi \& Searcy, 2015).

Consequently, the complexity of supply chains combined with the relatively neglected social sustainability component makes social sustainability assessment of supply chains a complex task. One of the major difficulties that companies need to face related to the complexity of social sustainability assessment is a quantification of social sustainability, i.e. development of quantitative social sustainability indicators (Varsei \& Polyakovskiy, 2017; Beske-Janssen et al., 2015). This difficulty also entails the determination of the aspects and impact categories that should be addressed (Hutchins \& Sutherland, 2008). Namely, existing models and frameworks for the social sustainability assessment don't enable a full assessment of supply chains and in order to easily access such complex systems, one should try to incorporate two or more existing methods/frameworks (Popovic \& Kraslawski, 2015). In that manner, Simões et al. (2016) use social LCA principles and GRI subcategories for the reinforcement of mid- and end- pint impact categories. The basic principle is to use GRI subcategories as end-point impact categories, for which Simões et al. (2016) proposed mid-point impact categories (Figure 1). As end-point impact categories, Simões et al. (2016) considered labour practices and decent work, human rights, society and product responsibility.

By considering the mid-point impact categories from Figure 1 one should be able to identify a set of quantitative social sustainability indicators that will allow the assessment of supply chains. The stress should be on the quantitative character of social sustainability indicators, as the quantitative indicators play a major role in process of decision making (Rametsteiner et al., 2011) and in the assessment of progress toward the social sustainability (Hák et al., 2016). On this context, the issues of social sustainability assessment have been addressed previously, however many studies were oriented on the performance of suppliers (Mani et al., 2016) and there is a scarcity of information and research oriented on the whole supply chains.

This work tries to fill the existing gaps by proposing a set of quantitative social sustainability indicators for the assessment of the society and product responsibility end-points impact categories (Figure 1). The remaining end-points impact categories are out of the scope of this research and will be addressed in a separate article. Thus the research question that emerges is following:

RQ 1. How to formulate quantitative indicators that will enable assessment of the social impacts of the whole supply chain on society and product responsibility aspects? 

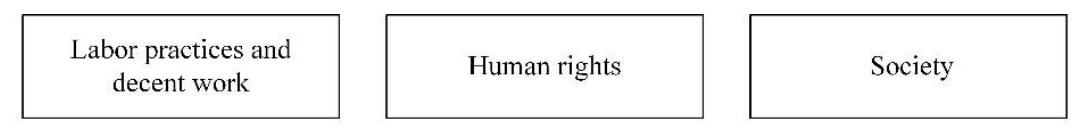

Product responsibility
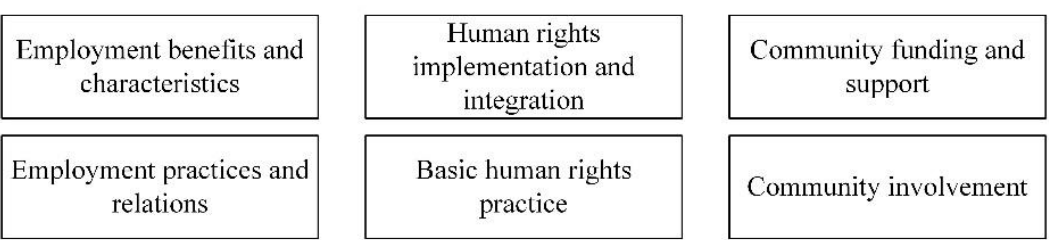

Consumer health and

$$
\text { safety }
$$

Community involvement

Product management and

consumer satisfaction

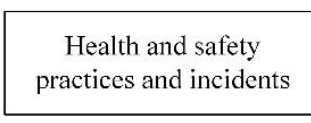
Training: education and
personal skills

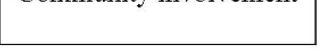

Corruption in business

Fair business operations
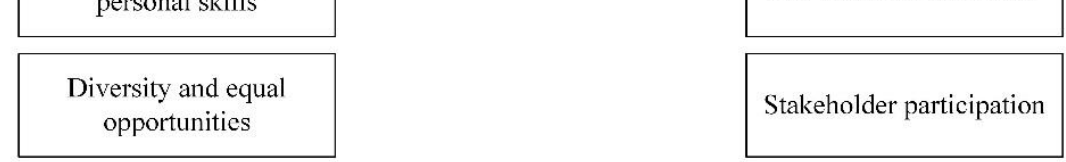

Stakeholder participation

Employee welfare

Innovation and

competitiveness

Figure 1. Classification of mid-point impact categories

Source: Simões et al., 2016

By answering to this research question the paper makes three contributions. First, is provided which aspects of social sustainability should be addressed. Second, social sustainability indicators are proposed and characterized by clear formulas, definition, and relevance. Third, by means of content analysis, it can be shown how different echelons of supply chain and different types of industry affect the relevance of proposed indicators.

\section{METHODOLOGY}

The methodology of this work follows six steps as presented in Figure 2. Each step is further described in details in paragraphs below.

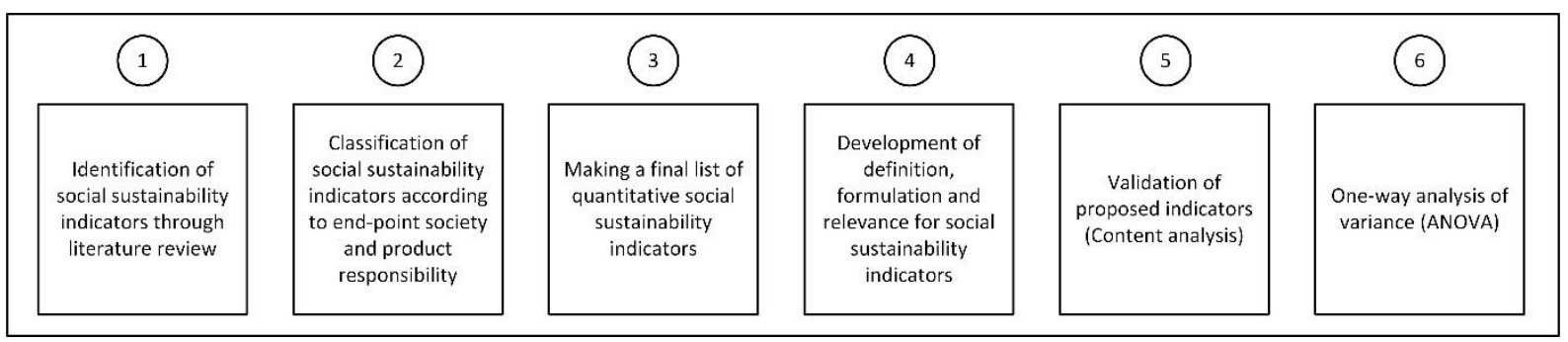

Figure 2. Applied methodology

Source: Authors' interpretation 
Step 1: Collection of relevant empirical material enabled the creation of the social sustainability indicators database. The aim was to get an overview of the social sustainability indicators that can address the issues related to end-points society and products responsibility (Figure 1).

The literature review was performed through online publishers and databases, such as Elsevier/Science Direct, Springer, Wiley online library, IChemE. The keywords used for the search process were: "social sustainability", "sustainability", "sustainable development", "social indicators", "sustainability indicators", "indicators", and "sustainability assessment". All collected material was in English, and it included journal articles, guidelines and standards that focus on sustainability, social sustainability, and (social) sustainability metrics and indicators. Thus initial search returned more than 300 articles.

Further reduction of the number of documents was done according to following criteria:

- Contains quantitative, semi-quantitative or qualitative indicators for social sustainability assessment

- Address issues related to mid-point of society and products responsibility as defined by Simões et al. (2016).

Utilization of these criteria has led to the reduction in the number of articles that are to be considered for detailed investigation. Thus the final sample included 45 articles.

Step 2: Information gathered by analysing the articles identified in the previous step helped in deriving indicators. The obtained 77 indicators were classified according to the mid-point impact categories belonging to the end-points society and product responsibility: 1) Community funding and support; 2) Community involvement; 3) Corruption in business; 4) Fair business operations; 5) Stakeholder participation; 6) Consumer health and safety; 7) Product management and consumer satisfaction (Simões et al. 2016). A definition summary of the above mentioned mid-point impact categories is presented in Table 1.

Table 1

Definition summary of mid-point impact categories

\begin{tabular}{|l|l|}
\hline \multicolumn{1}{|c|}{ Mid-point impact category } & \multicolumn{1}{c|}{ Definition summary } \\
\hline Community funding and support & $\begin{array}{l}\text { Contribution of the company in the community, such as cultural, } \\
\text { educational interactions and programs, or indirect financial support. }\end{array}$ \\
\hline Community involvement & $\begin{array}{l}\text { The positive and negative externalities that arise from the business and } \\
\text { have effect on society and their social performance. }\end{array}$ \\
\hline Corruption in business & $\begin{array}{l}\text { Evaluation of the business practice that is implemented for reducing the } \\
\text { corruption. }\end{array}$ \\
\hline Fair business operations & $\begin{array}{l}\text { Focuses on issues such as fair competition, lobbying and compliance with } \\
\text { legal requirements (e.g. potential impact on the employees, shareholders } \\
\text { and government). }\end{array}$ \\
\hline Stakeholder participation & $\begin{array}{l}\text { Focuses on stakeholders participations in organizational business } \\
\text { initiatives (e.g. involvement, influence and empowerment). }\end{array}$ \\
\hline Consumer health and safety & $\begin{array}{l}\text { Focuses on the product's environmental and social impact along life } \\
\text { cycle, as well as consumer's health and safety. }\end{array}$ \\
\hline $\begin{array}{l}\text { Product management and consumer } \\
\text { satisfaction }\end{array}$ & $\begin{array}{l}\text { Considers interactions between consumers, the product and the } \\
\text { company. }\end{array}$ \\
\hline
\end{tabular}

Source: Simões et al. (2017).

Step 3: Generation of the final list of the indicators is determined in the detailed analysis of the initial 77 indicators. Thus, it was opt to eliminate indicators with the following properties:

- Qualitative indicators, i.e. indicators of whose definition was not possible to derive quantitative equation;

- Reoccurrence of indicators, i.e. same indicator proposed in 2 or more different articles; 
- Indicators that cover the same issue, i.e. indicators with different denomination, but used to assess the same issue.

The utilization of these criteria reduced the initial set of 77 indicators to 24 indicators.

Step 4: The final 24 indicators, are to be clearly characterized by presenting a clear definition, its relevance and a mathematical formulation (aspects that were not presented in the literature). In order to acquire properties of effective indicators the methodology proposed by Feng and Joung (2009) was applied and the developed social sustainability indicators should have the following characteristics:

- Relevant - they show information about system that needs to be known;

- Easy to understand by all stakeholders - they have clear definition;

- Reliable - one can trust the information obtained by the indicator;

- Quantifiable - indicator can be numerically measured;

- Based on accessible data - accessibility of the indicators was verified by content analysis.

Step 5: Content analysis is performed in order to verify how the issues that are covered by indicators are addressed by companies. The objective of content analysis is to measure the number of the content specific keywords in the sustainability reports from the companies of all supply chains' echelons. It means that each indicator was characterized by content specific keyword which was then used for performing content analysis. The advantage of the content analysis is reflected in its objectivity and systematism. It is because content analysis is carried by following explicit rules that ensure objectivity of the analysis. Consequently, the results, i.e. inclusion or exclusion of particular content cannot be affected by researcher's ideas what further ensures systematism (Prasad, 2008).

Thus the content analysis should follow the next six steps (Hsien and Shannon, 2005):

a) Defining objective for using content analysis - the objective of the content analysis is to validate proposed social sustainability indicators, i.e. to analyse occurrence of the coding words in sustainability reports.

b) Choosing material that will be used for content analysis - sustainability reports from the companies belonging to the all echelons of supply chain were used as the material for the validation. In total, 141 sustainability reports from 25 countries were selected. The criteria that was used for selection considered that: (i) sustainability reports should follow principles and processes of G3.0 or G3.1 GRI guidelines; (ii) all reports should belong to the companies of all echelons (upstream, midstream and downstream, Meckenstock et al., 2015) based on the ranking in The Sustainability Yearbook listed in Dow Jones Global Index. Thus organizations should belong to the following 12 industries: (1) Mining, (2) Oil and Gas, (3) Materials, (4) Utilities, (5) Industrials, (6) Consumer Goods, (7) Electronics, (8) Automotive, (9) Transportation and Logistics, (10) Retail, (11) Telecommunications, and (12) Financials, where 1-4 are upstream companies, 5-8 midstream and 9-12 downstream companies; (iii) All reports should be written in English and should be stand-alone reports to allow easier comparison. The list of the reports is presented in Table A1 in Appendix section.

c) Selection of the units - units chosen for this analysis were keywords. It means that each indicator was assigned with specific keywords characterized as "recording unit", where recording unit presents smallest element of the text material that can be analysed (Flick, 2014). Each keyword was determined to be content specific and it can show how companies address the issues which are covered by the social sustainability indicators. The frequency of the coded keywords is considered as a suitable measure (Hsieh and Shannon, 2005). List of keywords is presented in the Table A2 in Appendix section.

d) Development of coding categories - coding categories are usually made to enable grouping of the coding units (Hsien and Shannon, 2005). Therefore, in this research indicators are used as coding categories, whereas coding units are keywords specifically designated for indicators. It means that 24 coding categories are considered, where each category presents one indicator. 
e) Coding of material - coding of material is done by NVivo computer software, where a query for each keyword separately was performed. Content specific words are then coded based on the defined coding scheme.

f) Analysing and interpretation of results - final representation of the results and their analysis are presented in sub-section "Indicators analysis and validation".

With all its advantages, content analysis still have issues with validity and reliability. It is because the findings can be affected by the subjectivity during the coding process. In order to ensure validity of analysis, coding scheme should be created so it can be "faithful to the theory in its orienting coders to the focal concepts" (Potter \& Levine-Donnerstein, 1999; p. 266). The coding schemes of this research were developed based on proposed indicators, their definition and issues that they address. Further, the coding schemes were tested in several sustainability reports and further revised until receiving satisfactory results. Issues related to reliability were eliminated by creating coding rules while doing machine coding (Meckenstock et al., 2015). This ensured stability and reproducibility of results (Krippendroff, 2004).

Step 6: Statistical analysis - this step includes performance of the one-way analysis of variance (ANOVA). The role of ANOVA was to examine if the indicators were generic for all echelons of the supply chain. It means that ANOVA would show if there is significant difference among the means of the results for different SC's echelons. The significant difference among the means of the groups was assessed through the P-value. If the P-value is lower than 0.05 it means that there is statistical significance among the means of the groups and null hypothesis is rejected (Bewick et al., 2004). In that case it is assumed that supply chain echelon has influence on the percentage of the keywords occurrence for that particular indicator.

\section{RESULTS AND DISCUSSION}

This section identifies the social sustainability indicators (sub-section 4.1.), with clear definition and relevance, that can be used for monitoring the progress toward social sustainability. Further sub-sections explore steps 5 and 6 of the methodology that aim to validate and analyse the proposed indicators. Validation is presented in sub-section 4.2 , after which is presented the preliminary model for social sustainability assessment of supply chain on different levels. Finally ANOVA statistical analysis (sub-section 4.3.) is presented in order to investigate how echelon levels may influence the importance of the indicators.

\subsection{Social sustainability indicators identification}

Identification of each indicator is based on the topics and issues addressed in existing literature. As discussed earlier, social sustainability indicators for end-point impact categories society and product responsibility are characterised with definition, quantitative formulation and relevance. Characterization of indicators is made to fill the existing gaps and to give them properties of effective indicators (section 3 , step 4).

\section{Community Funding and Support}

This mid-point category covers the company's contribution to the cultural and educational interactions and programmes in the community in terms of providing direct or indirect financial support (Simões et al., 2016). The indicators that encompass the issues defined with this mid-point category are:

Satisfaction of social needs (SSN) - total amount of investments for community social needs (Azapagic and Predan, 2000), such as education, good water quality, health services, etc.:

$$
S S N=\sum_{i=1}^{I} \sum_{n=1}^{N} I S_{n, i}(€)
$$

Where $i$ is an entity in given supply chain; $I$ is total number of entities in given supply chain; IS is a monetary investment in social need (e.g. education, good water quality, health services, etc.); $n$ is social need 
(e.g. education, good water quality, health services, etc.) in community where entity $i$ operates; $N$ is total number of social needs in community where entity $i$ operates.

Evaluation of investments to social needs can indicate: 1) contribution of company to satisfy social needs of community (Azapagic \& Predan, 2000); 2) willingness of company to support educational institutions such as schools and universities (Mani et al., 2014), as well as health institutions or public sectors.

Share of distributed revenues (SDR) - percentage of company's revenue provided to community (Lodhia \& Martin, 2014):

$$
S D R=\frac{\sum_{i=1}^{I} C C_{i}}{\sum_{i=1}^{I} R_{i}} \cdot 100(\%)
$$

Where $C C$ is monetary support of entity $i$ to community; $R$ is revenue of entity $i$.

Evaluation of this indicator can show: 1) involvement of company in social events, found-raising, daily basis actions, etc.; 2) ability of the company to help community. Target value for this indicator is as high as possible.

\section{Community Involvement}

The positive and negative externalities arising from the business can have effect on society social performance, the communities and the delivered social value (Simões et al., 2016). That is why this midpoint impact category aims to evaluate those externalities. Identified indicators for enabling those kind of measurements are presented as following: 2014):

Community complains $(\mathrm{Co} C)$ - number of complaints per revenue euro earned (Lodhia \& Martin,

$$
\operatorname{CoC}=\frac{\sum_{i=1}^{I} C_{c o m p, i}}{\sum_{i=1}^{I} R_{i}}(\text { complaints } / €)
$$

Where $C_{\text {comp }}$ is total number of community complains per entity $i$; $\mathrm{R}$ is revenue of entity $i$.

High number of community complains (e.g. because of offence, detriment, dust, noise, increased traffic flows, etc.) can lead to: 1) escalating complaints to disputes and grievances; 2) decreasing the reputation of the company. Target value for this indicator is 0 complaints per revenue euro earned.

Volunteering activities $(V A)$ - average number of hours spent for voluntary activities per entity per year:

$$
V A=\frac{\sum_{i=1}^{I} V_{t o t, i}}{I}(\mathrm{~h} / \mathrm{empl} \text {.) }
$$

Where $V_{\text {tot }}$ is total hours of volunteering per year per entity $i$.

Voluntary activities such as community work, caring and politics (Spangenberg \& Omann, 2006) are improving: 1) company's relation with community; 2) public image and reputation of company. Target value of this indicator is as high as possible.

\section{Corruption in Business}

In this mid-point category indicators should enable evaluation of the business practice implemented in order to reduce corruption (Simões et al., 2016). The identified social sustainability indicators for this midpoint category are:

Risk of corruption (RofC) - percentage of entities that assessed corruption risks (GRI, 2011):

$$
\operatorname{RofC}=\frac{\mathrm{C}}{\mathrm{I}} \cdot 100(\%)
$$

Where $C$ is the number of entities with assessed corruption risks.

Analysing of the company in terms of possible risks related to corruption can ensure reduction of effects that corruption can have on business, such as: 1) reduced business credibility; 2) loss of public trust. Target value for this indicator is $100 \%$. 
Anti-corruption trainings $(A C T)$ - percentage of entities with trainings for anti-corruption policies and procedures (GRI, 2011):

$$
A C T=\frac{E_{a c}}{I} \cdot 100(\%)
$$

Where $E_{a c}$ is number of entities that provide trainings for anti-corruption policies and procedures.

Organising employee's trainings against corruption are showing: 1) employer's willingness to reduce the risk of corruption; 2) implementation of anti-corruption policies and procedures. Target value for this indicator is $100 \%$.

\section{Fair Business Operations}

With this mid-point issues such as fair competition, lobbying and compliance with legal requirements are addressed. The main focused is the potential impact on the employees, shareholders and government (Simões et al., 2016). The identified indicators for this mid-point category are:

Support for political parties (SPP) - percentage of the revenue allocated to support political parties in year (GRI, 2011):

$$
S P P=\frac{\sum_{i=1}^{I} F S_{i}}{\sum_{i=1}^{I} R_{i}} \cdot 100(\%)
$$

Where FS is financial support for political parties per entity $i ; R$ is revenue of entity $i$.

Financial support given to political parties can indicate: 1) transparency in political dealing and relationships of the organization with political parties; 2) engagement in political funding. Target value for this indicator can be regulated by law, as many countries have legislations regarding financial supports to political parties (GRI, 2011).

Anti-competitive behaviour $(A C B)$ - average number of legal actions conducted per year (GRI, 2011):

$$
A C B=\frac{\sum_{i=1}^{I} L A_{i}}{I}(\text { no. } / \text { year })
$$

Where $L A$ is number of legal actions in entity $i$.

Execution of legal actions for anti- competitive behaviour, anti-trust, and monopoly practices and their outcomes can lead to: 1) effects on customer choice; 2) change in pricing the products (GRI, 2011). Target value for this indicator is 0 .

Sanctions for non-compliance with law (NCL) - average annual number of monetary and nonmonetary sanctions for non-compliance with laws (GRI, 2011):

$$
N C L=\frac{\sum_{i=1}^{I} F_{i}}{I}
$$

Where $F$ is total number of monetary and non-monetary sanctions fines per entity $i$.

Low value of this indicator can show: 1) company's compliance with laws, such as conform to a certain performance parameters (GRI 2011); 2) companies' will to move toward sustainability. Target value for this indicator is 0 .

\section{Stakebolder Participation}

Stakeholder participations such as involvement, influence and empowerment in the organisational business initiatives are considered with this mid-point category (Simões et al. 2016). It is important to make the evaluation of stakeholders' participation, since that helps in shaping strategies and implementing better social sustainable practices (Simões et al., 2016). The indicators identified are described as follows:

Strategic cooperation $\left(S T C_{\text {avg }}\right.$ - average number of strategic cooperation, such as alliances, licensing and agreements per year:

$$
S T C_{a v g}=\frac{\sum_{i=1}^{I} S T C_{i}}{I}
$$

Where $S T C$ is number of strategic cooperation in entity $i$. 
Strategic cooperation (Mehralian et al., 2013) can lead to: 1) acquisition of new knowledge from other firms; 2) improving productivity employees.

Community forums $\left(\mathrm{CF}_{t o t}\right)$ - number of community forums, such as web forum for announcing information open for community (open for comments of stakeholders), organised in the whole supply chain per year (Labuschagne et al., 2005):

$$
C F_{\text {tot }}=\sum_{i=1}^{I} C F_{i} \text { (no./year) }
$$

Where $C F$ is number of community forums per entity $i$ in given supply chain.

The number of community forums provided by the company is showing: 1) ability of company to include stakeholders in process of decision making; 2) company's respecting of stakeholders' opinions. Desired values of this indicator are as high as possible.

Complaint channels $\left(C C_{t o t}\right)$ - annual number of channels where stakeholders can complain (Labuschagne et al., 2005):

$$
C C_{\text {tot }}=\sum_{i=1}^{I} C C_{i}
$$

Where $C C$ is number of complaint channels in entity $i$.

Channels for complains can be provided in form of phone complains, online, cell phone applications, counter services, etc. The number of channels provided for complains can: 1) lead to shaping the strategy of company according the stakeholders' needs; 2) show the companies' willingness to accept complain. Target value for this indicator is as high as possible.

Effectiveness in response to information request (ERIR) - average number of days needed to answer to all requests (Hassini et al. 2012):

$$
E R I R=\frac{\sum_{i=1}^{I} \sum_{a=1}^{A} D_{a, i}}{\sum_{i=1}^{I} R_{i}}
$$

Where $a$ is number of requests for information in entity $\mathrm{i} ; A$ is total number of requests for information per entity $i ; D$ is days needed to answer on request for information per entity $i$.

Regular responses to requests, such as information about the product or any publicly available information legally guaranteed are ensuring: 1) good communication with all stakeholders; 2) good availability of information.

Employment involvement in decision making $(E m p D M)$ - percentage of entities that involve employees (stakeholders) in decision making:

$$
\operatorname{EmpDM}=\frac{E_{d m}}{I} \times 100(\%)
$$

Where $E_{d m}$ is number of entities that involve employees (stakeholders) in decision making process.

Involvement of the employees in the process of decision making is showing: 1) that the company respect the opinions of the employees; 2) initiative in implementing better social sustainability practice. Target value for this indicator is $100 \%$.

\section{Consumer Health and Safety}

This mid-point category focuses mainly on product, i.e. the environmental and social impact of the product across its life cycle as well as consumer health and safety threats from product (Simões, 2014). The evaluation of this mid-point category can be made with the next indicators:

$\mathrm{CO} 2$ emission control (CO2) - mass of $\mathrm{CO} 2$ emission per one product unit:

$$
\mathrm{CO} 2=\frac{\sum_{i=1}^{I} m\left(\mathrm{CO}_{2}\right)_{i}}{P_{\text {tot }}}(\mathrm{kg} \mathrm{CO} 2 / \text { product })
$$

Where $m\left(\mathrm{CO}_{2}\right)$ is $\mathrm{CO}_{2}$ emission per entity $i$; Ptot is total number of final products.

It was shown that reduction of carbon emission can have positive effect on quality of life (Ferris, 2010), but also monitoring the levels of $\mathrm{CO} 2$ emission is significant: 1) due to increased awareness of customers 
about possible negative impacts on environment; 2) because it can indicate concern about environmental impact of product across life cycle. Target value for this indicator is $0 \mathrm{~kg} \mathrm{CO} 2 /$ product.

Health complains (HCavg) - total number of complaints (related to health) per product (Mehralian et al., 2013):

$$
H C_{\text {avg }}=\frac{\sum_{i=1}^{I} H C_{i}}{P_{\text {tot }}}(\text { compl. } / \text { poduct })
$$

Where $H C$ is total number of health complains per entity $i$; $P_{t o t}$ is total number of final products of the given supply chain.

Large number of consumer's complains on product related to health can show: 1) negative social impact of the product; 2 ) inability of company to provide healthy and safe product to the consumers. Target value for this indicator is 0 complains per product.

Product Management and Consumer Satisfaction

With this mid-point impact category interactions between the consumers, the product and the company are considered. The indicators' aim in this mid-point is to evaluate issues related to product commercialisation, brand awareness and legal consumer services procedures (Simões et al., 2016):

Lead time (LT) - Lead time can be defined as time required to finish supply chain cycle (Ahi and Searcy 2015), i.e. a time required for a process to end. This indicator thus evaluates ratio between total number of products that have been delivered in planned lead time and total number of products delivered:

$$
L T=\frac{\sum_{i=1}^{I} P_{d t, i}}{\sum_{i=1}^{I} P_{t o t, i}}
$$

Where $P_{d t}$ is number of products delivered in required time per entity $i$ for a given supply chain; $P_{t o t}$ is total number of products per entity $i$ for a given supply chain.

Short lead time shows: 1) ability of company to provide customer with product in desirable time; 2) the company's commitment to fulfil customer needs. Desirable values for this indicator are $100 \%$

Percentage of repeated customers $\left(R C_{\text {ratio }}\right)$ - percentage of repeated customers (Ali et al., 2013):

$$
R C_{\text {ratio }}=\frac{\sum_{i=1}^{I} R C_{i}}{\sum_{i=1}^{I} C_{\text {tot }, i}} \times 100(\%)
$$

Where $R C$ is number of repeated customers per entity $i ; C_{t o t}$ is total number of customers per entity $i$.

High value of this indicator indicate: 1) satisfaction of customers with company's business and products; 2) good performance of the company. Target value for this indicator is $100 \%$.

Average period of relationship (REL) - average duration of contracts that company has with their clients (Mehralian et al., 2013):

$$
R E L=\frac{\sum_{i=1}^{I} \sum_{c=1}^{C} R Y_{c, i}}{\sum_{i=1}^{I} C_{i}} \text { (years } / \text { customer) }
$$

Where $R Y$ is years of relation with customer in entity $i$; $C$ is total number of customers in entity $i$.

Long duration of the contracts can show: 1) customer's loyalty to the business; 2) good cooperation between company and customer. Desirable values for this indicator are as high as possible.

Traceability of product (TP) - Traceability is defined as "the ability to identify and trace the history, distribution, location, and application of the products, parts, and materials, to ensure the reliability of sustainably claims, in the areas of human rights, labour (including health and safety), the environment and anti-corruption" (United Nations Global Compact, 2014; p. 6). Thus this indicator aims in calculating the percentage of products with successful traceability in supply chain per year:

$$
T P=\frac{P_{s t}}{P_{\text {tot }}} \times 100(\%)
$$

Were $P_{s t}$ is number of products with successful traceability in the whole supply chain; $P_{t o t}$ is total number of final products of given supply chain. 
Traceability of the product keeps track of possible impacts from nature to consumer satisfaction and health in the whole supply chain (Borit and Santos 2015). Thus, traceability is showing how production is handled (e.g. safe working environment, equal wages among employees, low environmental impact) through whole supply chain, what further leads to: 1) better acceptance by consumers; 2) increased sales of the product. Target value for this indicator is $100 \%$.

Inspection and quality audits (IQA) - percentage of suppliers and contractors that were the subject to inspections and quality audits, in order to ensure compliances with the product claims on the quality labels (Tahir and Darton, 2010):

$$
I Q A=\frac{\sum_{i=1}^{I} S C_{i n s p, i}}{\sum_{i=1}^{I} S C_{t o t, i}} \times 100(\%)
$$

Where $S C_{\text {insp }}$ is number of contractors of entity $i$ that are subject to inspections; $S C_{\text {tot }}$ is total number of contractors of entity $i$.

Inspection on suppliers and contractors through supply chain can lead to: 1) increased trust with suppliers and contractors; 2 ) better and prolonged cooperation. Target value for this indicator is $100 \%$.

Compliance with regulations $(C R)$ - average number of incidents of non-compliance with regulations and voluntary codes concerning marketing communications, including advertising, promotion, and sponsorship occurred per year (GRI, 2011):

$$
C R=\frac{\sum_{i=1}^{I} I N_{i}}{I}(\text { no. } / \text { year })
$$

Where $I N$ is total number of incidents in entity $i$ per year.

The number of incidents of non-compliance with regulations and voluntary codes concerning marketing communications, including advertising, promotion, and sponsorship can lead to: 1) fine or penalty; 2) warning (GRI, 2011). Target value for this indicator is 0 incidents per year.

Information infringement (II) - number of reported cases of information infringement, such as credibility of branding, labelling and marketing information:

$$
I I=\frac{\sum_{i=1}^{I} R C_{i n f, i}}{I}
$$

Where $R C_{i n f}$ is total number of reported cases of information infringement in entity $i$.

Credibility of branding, labelling and marketing information is important because of: 1) social acceptability of product (Tahir \& Darton, 2010); 2) elimination of penalties for information infringement. Target value for this indicator is 0 .

Customer privacy $(C P)$ - number of substantiated complaints regarding jeopardizing customer privacy (GRI, 2011):

$$
C P=\frac{\sum_{i=1}^{I} \operatorname{COM}_{i}}{I}
$$

Where COM is total number of complaints per entity $i$.

Breaches of customer privacy and losses of customer data can lead to: 1) high costs; 2) loosing of customer trust. The target value for this indicator is 0 complains per year.

\subsection{Validation}

As previously mentioned content analysis is conducted for the purpose of validating the developed indicators. Validation should show how issues covered by the indicators are addressed in the sustainability reports of the companies of all supply chains' echelons. It is done by analysing occurrence of the content specific keywords (Table A2) in the sustainability reports. In total, 141 sustainability reports were selected for this analysis (see section "Methodology"). The results obtained from the content analysis for the 24 
indicators are shown in Figure 3, from where it can be seen that most part of the indicators identified are used in the SC sustainability reports.

The summary of content analysis presented in Figure 3 shows that the content specific keywords are occurring in the sustainability reports of companies belonging to all echelons of supply chain. This indicates that the issues covered by the proposed indicators have been addressed by the companies, thus indicating that the proposed indicators can be used for the social sustainability assessment of the whole supply chain. However in the Figure 3 it can be also observed differences of the keyword occurrence. Thus one can identify CO2 emission control $\left(\mathrm{CO}_{2}\right)$, risk of corruption $(\mathrm{R} o f \mathrm{C})$, percentage of repeated customers $\left(R C_{\text {ratio }}\right)$, employees trained for anti-corruption $(A C T)$ and strategic cooperation $\left(S T C_{\text {avg }}\right)$ as top five indicators, i.e. indicators with the highest percentage of keyword occurrence, what can indicate that these indicators are more reported and assessed by the companies. It is reasonable that $\mathrm{CO} 2$ emission has the highest keywords occurrence, as $\mathrm{CO} 2$ presents the highest percentage of GHGs (greenhouse gases) that have a great influence on climate change and quality of life (Ferriss, 2010). What can also be observed from Figure 3 is that the keyword occurrence for $\mathrm{CO} 2$ emission is highest for midstream echelon. That can be explained by the fact that midstream echelon involve production and assembly (Meckenstock et al., 2015), what is one of the main sources of CO2 emission (Martínez \& Fransoo, 2017). Further, it can be observed that corruption is of high concern, where percentage of keyword occurrence decreases by moving from upstream to downstream echelon. This trend is expected as upstream companies are from oil and gas, mining, materials and utilities sector, which were identified as sectors with highest risk for corruption by Bribe payers index report from 2011 (Hardoon \& Heinrich, 2011). Percentage of repeated customers is reasonably in the top five indicators as customer loyalty is essential for business' profit and its survival (Kasemsap, 2016). And finally, strategic cooperation reflects its importance in fulfilling customers' needs and maximizing the profit, benefits and efficiency of supply chains (Omri, 2010).

Apart from top five, as bottom five reported indicators employment involvement in decision making (EmpDM), information infringement (II), effectiveness in response to information request (ERIR), customer privacy $(C P)$ and traceability of product (TP) are identified. The low values of keyword occurrence are indicating a reduced companies' interest in the issues covered by these indicators. Thus, even though involvement of employees in decision making is significant for various reasons (improving job satisfaction, increased commitment of employees, etc.) (Irawanto, 2015) results of content analysis showed low values, i.e. companies' lower interest in this issue. Even tough through supply chain is possible to request for information, the companies used for content analysis didn't not put much attention to this issue in their sustainability reports. Similarly, information infringement and customer privacy didn't receive enough interest from the companies. Finally, the traceability of products is most common in the food industry as recently there was many food related scandals, such as the presence of horsemeat in frozen beef products (Borit \& Santos, 2015). Thus by considering the sources of sustainability reports, i.e. the sectors whose sustainability reports were used, it is expected that results of the content analysis show low values for indicator traceability of products. Especially because only several analysed sustainability reports belong to the food sector.

Additionally, as it can be noticed from the Figure 3 there are significant differences among relative frequencies of the keywords between indicators. For that reason, it was decided to investigate what can influence this behaviour.

Consequently a breakdown by the type of industry is made (Table 2). Thus, from Table 2 can be noticed that some indicators are showing zero values for particular types of industries. These zero values go in line with the bottom five indicators, i.e. they are those that show zero values for the particular types of the industries. So by observing Figure 4a, one can notice the percentage of industries with zero values for particular indicators. For instance indicator information infringement (II) showed zero values for majority 
of upstream industries. While indicator employment involvement in decision making (EmpDM) showed zero values for almost equal number of industries of all echelons. This kind of variation can indicate that the frequency of keywords can be affected by the echelon level influence.

However different observation can be obtained when observing the percentage of indicators that were not addressed by a particular sector (Figure 4b). Namely it can be noticed that utilities, automotive, consumer goods and telecommunication are not showing zero values for any of the proposed indicators. It means that these sectors are addressing all issues covered by the proposed indicators. While oil and gas showed highest percentage of indicators with zero values, but only for the indicators of 'Product management and customer satisfaction' aspect, more specifically for indicators traceability of products (TP), information infringement (II) and customer privacy $(C P)$. These observations can indicate the influence of the type of sector on the relative frequencies of the keywords, meaning that the relevance of the indicators can be affected by the type of sector in the echelon of supply chain.

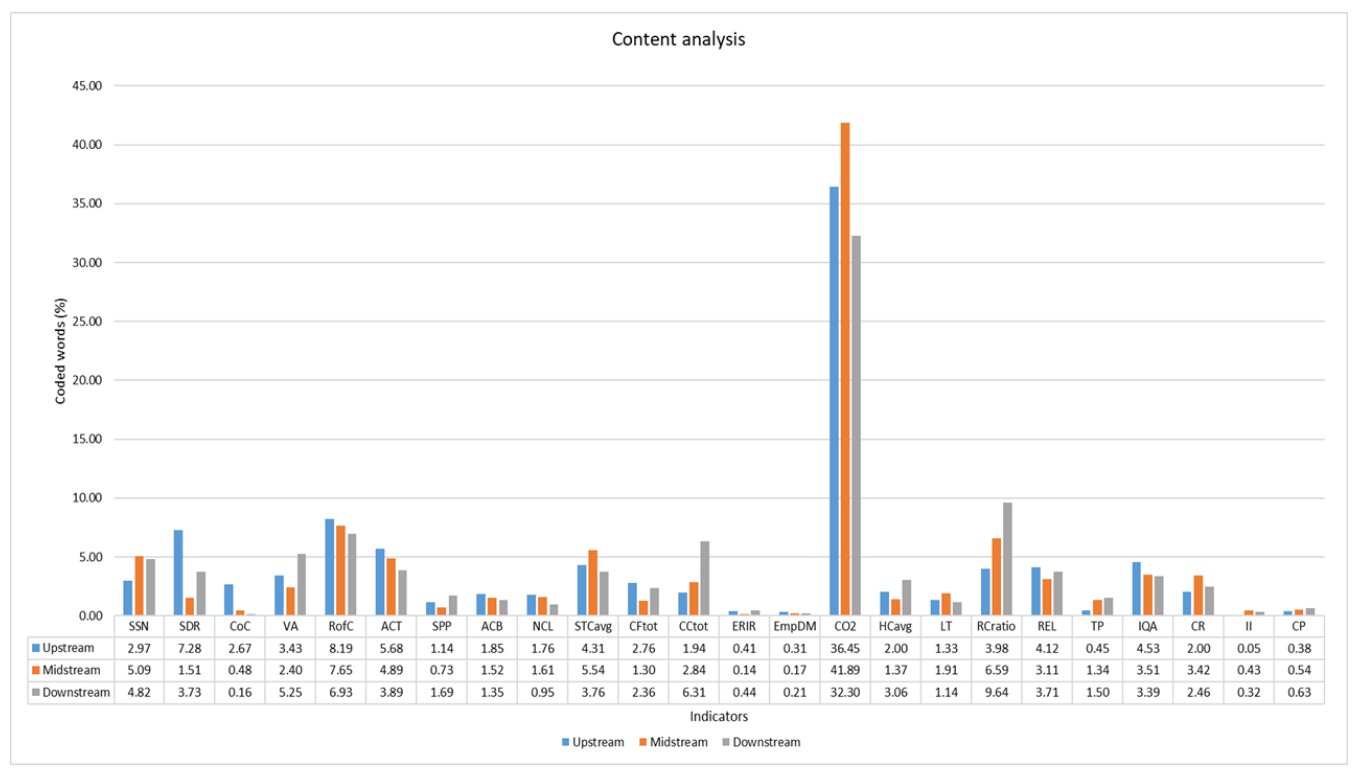

Figure 3. Overall results of content analysis

Source: Authors' results

Based on previous results and discussion three conclusions can be drawn. First, by observing the overall result of the content analysis (Figure 3) one can comprehend that all indicators can be considered as generic and thus can be used for the assessment of the whole supply chain. However further analysis of the content analysis can indicate that the keyword occurrence, i.e. importance of the indicators depends on:

Echelon level, i.e. the importance of indicators depends on the type of echelon;

Type of industry, i.e. different industrial sectors prefer different social sustainability aspects and indicators.

Similarly, previous literature showed that the majority of the approaches for sustainability assessment differ in their perspectives, from development and usage of general set of indicators to the development and usage of industry, process or product specific indicators (Veleva et al., 2001; Labuschagne et al., 2005; Rahdari \& Rostamy, 2015; Fritz et al., 2017). The conclusions of this work and the findings from previous literature, can be summarized as model for the assessment of social sustainability of supply chains (Figure 5). The aim of this model is to address the issue of social sustainability on 3 different levels i.e. supply chain level, echelon level and industry level. Thus it can be stated that there should exist three different sets of indicators: 
- Generic indicators, suitable for the social sustainability assessment of 7 mid-point impact categories (designated by colour in Figure 5) of the whole supply chain;

- Echelon indicator, suitable for the social sustainability assessment of 7 mid-point impact categories (designated by colour in Figure 5) of each echelon level (upstream, midstream, downstream);

- Specific indicators, suitable for the social sustainability assessment of 7 mid-point impact categories (designated by colour in Figure 5) at industry level.

Table 2

Percentage of coded words for upstream, midstream and downstream echelon - breakdown by type of industry

\begin{tabular}{|c|c|c|c|c|c|c|c|c|c|c|c|c|c|}
\hline \multirow[b]{2}{*}{ Mid-point } & \multirow[b]{2}{*}{ Ind. } & \multicolumn{4}{|c|}{ Upstream* } & \multicolumn{4}{|c|}{ Midstream** } & \multicolumn{4}{|c|}{ Downstream*** } \\
\hline & & UP1 & UP2 & UP3 & UP4 & MID1 & MID2 & MID3 & MID4 & DOWN1 & DOWN2 & DOWN3 & DOWN4 \\
\hline \multirow{2}{*}{$\begin{array}{l}\text { Community } \\
\text { funding and } \\
\text { support } \\
(\mathrm{CF} \& S)\end{array}$} & SSN & 1.10 & 1.24 & 7.61 & 2.16 & 8.08 & 2.83 & 5.83 & 3.61 & 0.74 & 13.45 & 2.24 & 2.84 \\
\hline & SDR & 1.10 & 17.81 & 4.99 & 2.72 & 0.82 & 3.44 & 0.61 & 1.16 & 6.67 & 4.06 & 1.53 & 2.65 \\
\hline \multicolumn{2}{|c|}{ Total CF\&S } & 2.20 & 19.05 & 12.60 & 4.88 & 8.90 & 6.27 & 6.43 & 4.77 & 7.41 & 17.51 & 3.78 & 5.49 \\
\hline \multirow{2}{*}{$\begin{array}{l}\text { Community } \\
\text { involvement } \\
(\mathrm{CI})\end{array}$} & $\mathrm{CoC}$ & 0.88 & 7.25 & 0.26 & 0.75 & 0.18 & 0.74 & 0.36 & 0.64 & 0 & 0.51 & 0.12 & 0 \\
\hline & VA & 1.54 & 3.11 & 4.99 & 4.69 & 1.82 & 3.44 & 2.55 & 1.80 & 6.17 & 3.55 & 8.62 & 2.65 \\
\hline \multicolumn{2}{|c|}{ Total CI } & 2,42 & 10.35 & 5.25 & 5.45 & 2.00 & 4.18 & 2.91 & 2.45 & 6.17 & 4.06 & 8.74 & 2.65 \\
\hline \multirow{3}{*}{\multicolumn{2}{|c|}{\begin{tabular}{|c|c|}
$\begin{array}{c}\text { Corruption in } \\
\text { business (CinB) }\end{array}$ & RofC \\
Total CinB \\
Total
\end{tabular}}} & 5.29 & 12.42 & 7.87 & 6.57 & 7.54 & 6.39 & 3.52 & 13.14 & 7.65 & 6.35 & 5.79 & 7.95 \\
\hline & & 1.76 & 8.49 & 9.97 & 1.97 & 2.63 & 6.51 & 4.37 & 6.06 & 2.72 & 3.30 & 3.31 & 6.25 \\
\hline & & 7.05 & 20.91 & 17.85 & 8.54 & 10.17 & 12.90 & 7.89 & 19.20 & 10.37 & 9.64 & 9.09 & 14.20 \\
\hline \multirow{3}{*}{\begin{tabular}{|l|} 
Fair business \\
operations \\
(FBO)
\end{tabular}} & SPP & 1.54 & 1.04 & 0.52 & 1.50 & 1.27 & 0.74 & 0.12 & 0.77 & 3.95 & 1.27 & 1.18 & 0.38 \\
\hline & $\mathrm{ACB}$ & 2.20 & 1.45 & 1.84 & 1.60 & 1.73 & 1.35 & 1.70 & 1.29 & 0.49 & 1.52 & 1.30 & 2.08 \\
\hline & NCL & 3.08 & 0.62 & 1.05 & 2.16 & 1.73 & 1.35 & 1.94 & 1.42 & 0.99 & 0.76 & 0.71 & 1.33 \\
\hline \multicolumn{2}{|c|}{ Total FBO } & 6.83 & 3.11 & 3.41 & 5.26 & 4.72 & 3.44 & 3.76 & 3.48 & 5.43 & 3.55 & 3.19 & 3.79 \\
\hline \multirow{5}{*}{$\begin{array}{l}\text { Stakeholder } \\
\text { participation } \\
\text { (SP) }\end{array}$} & STC $_{\text {avg }}$ & 2.42 & 4.97 & 2.89 & 5.92 & 7.36 & 8.11 & 4.00 & 2.71 & 2.72 & 5.33 & 4.72 & 2.27 \\
\hline & $\mathrm{CF}_{\text {tot }}$ & 1.10 & 6.42 & 1.31 & 1.88 & 1.00 & 2.21 & 1.09 & 0.90 & 1.48 & 2.03 & 2.72 & 3.22 \\
\hline & $\mathrm{CC}_{\text {tot }}$ & 1.32 & 1.04 & 1.31 & 4.13 & 2.00 & 1.35 & 5.95 & 2.06 & 4.69 & 5.08 & 11.10 & 4.36 \\
\hline & ERIR & 0.66 & 0.21 & 0.26 & 0.47 & 0.09 & 0.12 & 0.36 & 0 & 0.99 & 0 & 0.59 & 0.19 \\
\hline & EmpDM & 0 & 0.62 & 0.79 & 0.47 & 0.45 & 0.25 & 0 & 0 & 0 & 0 & 0.47 & 0.38 \\
\hline \multicolumn{2}{|c|}{ Total SP } & 5.51 & 13.25 & 6.56 & 12.86 & 10.90 & 12.04 & 11.41 & 5.67 & 9.88 & 12.44 & 19.60 & 10.42 \\
\hline \multirow{2}{*}{\begin{tabular}{|l|l|}
$\begin{array}{l}\text { Consumer } \\
\text { health } \\
\text { safety }\end{array}(\mathrm{CH} \& \mathrm{~S})$ \\
\end{tabular}} & $\mathrm{CO} 2$ & 58.81 & 15.32 & 30.45 & 42.25 & 41.05 & 37.84 & 43.81 & 44.85 & 24.94 & 27.41 & 27.04 & 49.81 \\
\hline & $\mathrm{HC}_{\text {avg }}$ & 1.76 & 0.83 & 3.94 & 2.07 & 2.18 & 1.97 & 1.09 & 0.26 & 8.40 & 2.79 & 1.06 & 0 \\
\hline \multicolumn{2}{|c|}{ Total CH\&S } & 60.57 & 16.15 & 34.38 & 44.32 & 43.23 & 39.80 & 44.90 & 45.10 & 33.33 & 30.20 & 28.10 & 49.81 \\
\hline \multirow{8}{*}{$\begin{array}{l}\text { Product } \\
\text { management } \\
\text { and consumer } \\
\text { satisfaction } \\
\text { (PM\&CS) }\end{array}$} & SCCT & 1.76 & 0 & 1.57 & 1.97 & 1.91 & 0.25 & 2.67 & 2.84 & 2.47 & 0.76 & 0.94 & 0.38 \\
\hline & $\mathrm{RC}_{\text {ratio }}$ & 5.07 & 1.66 & 4.72 & 4.88 & 8.72 & 2.09 & 6.92 & 8.63 & 10.12 & 8.88 & 14.05 & 5.49 \\
\hline & REL & 3.74 & 6.83 & 6.56 & 1.41 & 3.63 & 3.93 & 2.31 & 2.58 & 8.40 & 2.03 & 3.07 & 1.33 \\
\hline & TP & 0.22 & 0.41 & 0 & 1.31 & 0.09 & 3.69 & 1.21 & 0.39 & 1.23 & 3.05 & 1.53 & 0.19 \\
\hline & IQA & 1.32 & 6.21 & 6.04 & 6.01 & 3.18 & 2.95 & 5.22 & 2.71 & 1.48 & 5.33 & 2.01 & 4.73 \\
\hline & $\mathrm{CR}$ & 2.86 & 1.66 & 1.05 & 2.35 & 2.09 & 8.11 & 2.06 & 1.42 & 3.46 & 1.78 & 3.66 & 0.95 \\
\hline & II & 0 & 0 & 0 & 0.19 & 0.27 & 0.12 & 1.21 & 0.13 & 0.25 & 0.25 & 0.59 & 0.19 \\
\hline & $\mathrm{CP}$ & 0.44 & 0.41 & 0 & 0.56 & 0.18 & 0.25 & 1.09 & 0.64 & 0 & 0.51 & 1.65 & 0.38 \\
\hline \multicolumn{2}{|c|}{ Total PM\&CS } & 15.42 & 17.18 & 19.95 & 18.69 & 20.07 & 21.38 & 22.69 & 19.33 & 27.41 & 22.59 & 27.51 & 13.64 \\
\hline \multicolumn{2}{|c|}{ TOTAL } & 100 & 100 & 100 & 100 & 100 & 100 & 100 & 100 & 100 & 100 & 100 & 100 \\
\hline
\end{tabular}

Source: Authors' results. *UP1 - Materials, UP2 - Mining, UP3 - Oil\&Gas, UP4 - Utilities; **MID1 Automotive, MID2 - Consumer goods, MID3 - Electronics, MID4 - Industrials; ***DOWN1 - Financials, DOWN2 - Retail, DOWN3 - Telecommunication, DOWN4 - Transport\&Logistics 


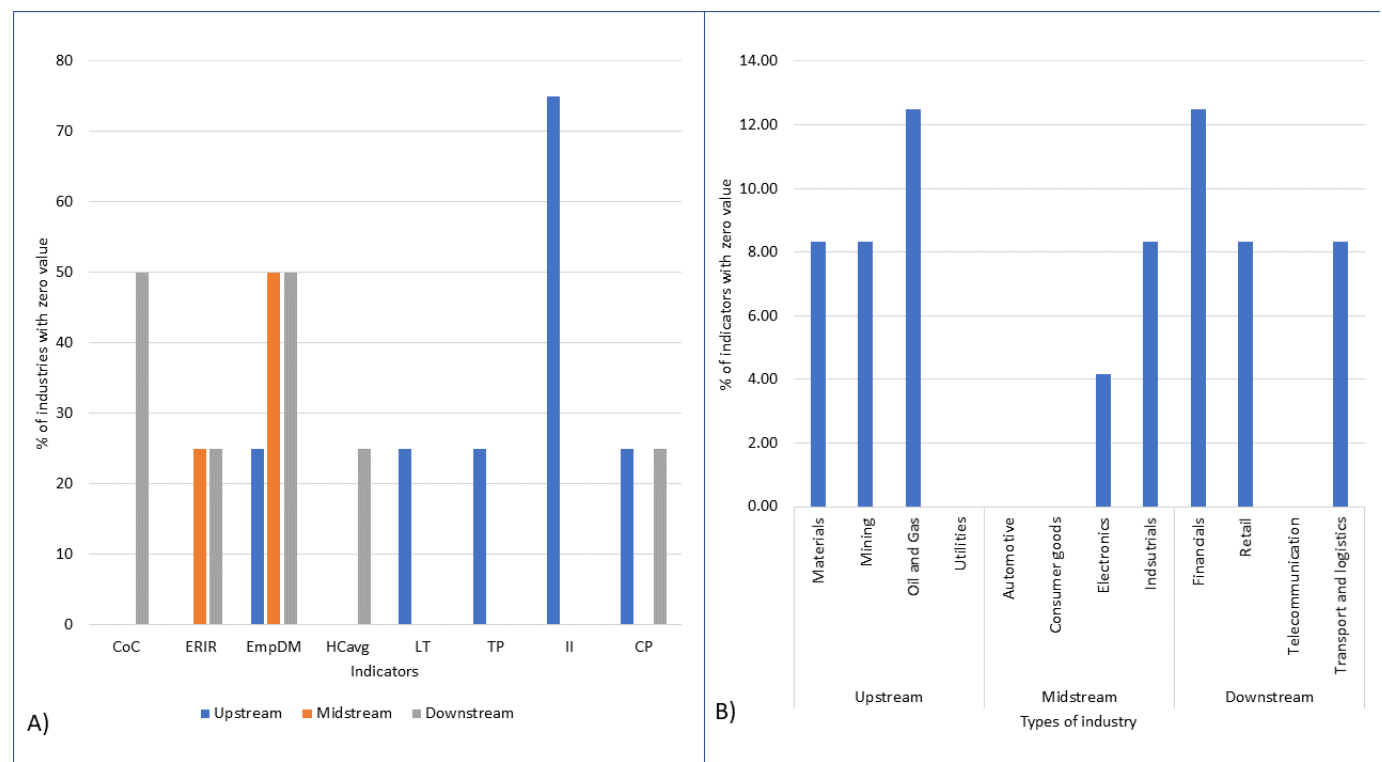

Figure 4. a) Percentage of industries with zero values for particular indicators: b) Percentage of indicators with zero values (breakdown by type of industry)

Source: Authors' results.

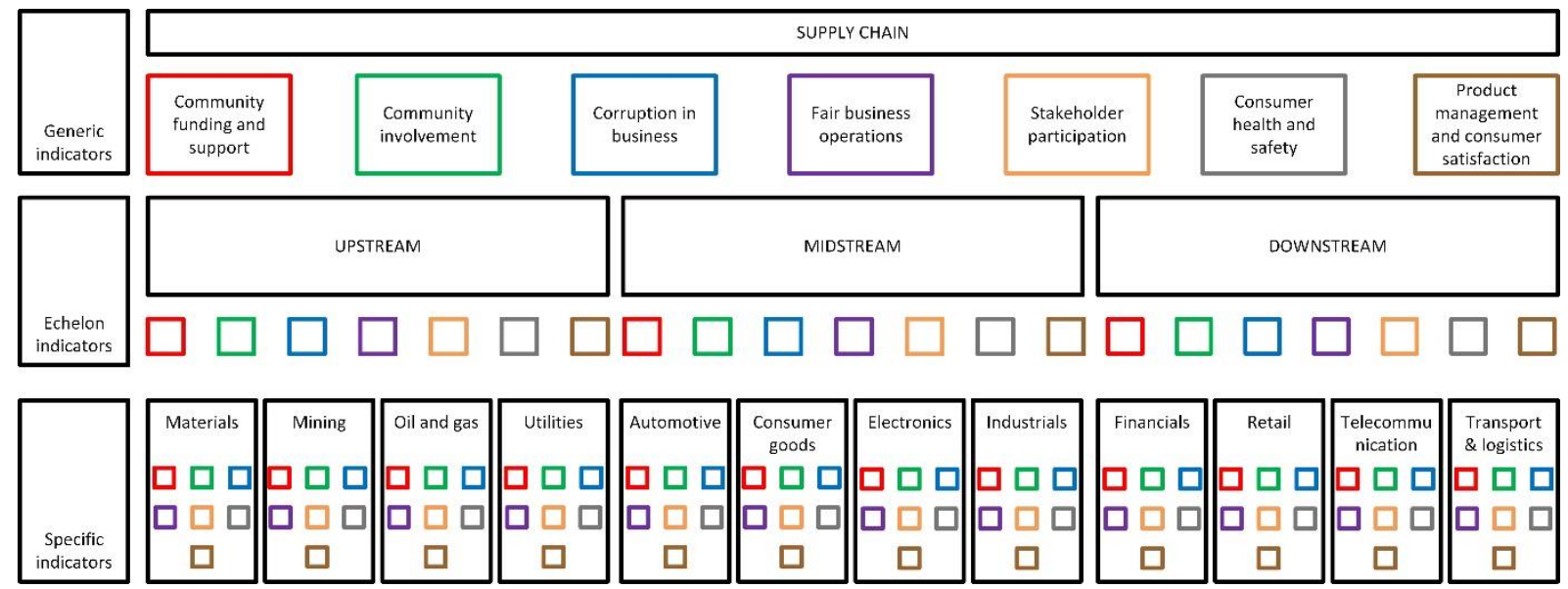

Figure 5. Model for social sustainability assessment of supply chains

Source: Authors' results

Following these conclusions, the influence of echelon level on the indicators' importance will be verified, while the other conclusions will be subject of future work. Primarily was selected to evaluate if echelon level have some effect on the keyword occurrence. This is done by ANOVA analysis that shows if there is any statistical significance among the mean values of the content analysis. Obtained results are presented in following sub-section.

\subsection{Analysis of variance (ANOVA)}

ANOVA analysis was performed in order to check if the differences in the relative keyword occurrence are affected by the echelon level. That will show the effect of echelon level on the usage of indicators. For that matter p-value is observed, i.e. if p-value is below 0.05 it means that there is statistical difference 
between mean values of percentage of keywords for the different echelons and thus it indicates that echelon level affects the percentage of keywords occurrence. More specifically that importance of indicators depends on the SCs' echelon level.

Due to huge data variety, an equal sample size had to be generated based on the following criteria: 1) picking the lowest common number of companies that address issues covered by more than $50 \%$ of indicators (> 12 indicators), i.e. each of them gathered 11 companies in total; 2) calculation of mean relative value of keywords occurrence for each company and picking those companies which had a higher mean relative value. Due to fact that whole sample of 141 sustainability repots included much more companies that addressed issues covered by more than $50 \%$ of indicators (more than $30 \%$ of total sample), the overall results from Figure 3 were also included in the sample that so as not to miss important data. Consequently, the final sample for ANOVA analysis was 36.

Results of ANOVA analysis are shown in Table 3, from where it can be observed that all p-values are above 0.05 . So there is no statistical difference between the mean values of word counts of different echelons. In that case it can be concluded that echelon level doesn't influence keyword frequency in sustainability reports, i.e. all indicators can be observed as generic.

Table 3

Results of ANOVA analysis

\begin{tabular}{|c|c|c|c|c|c|}
\hline $\begin{array}{l}\text { Mid-point impact } \\
\text { category }\end{array}$ & Indicator & P-Value & Mid-point impact category & Indicator & P-Value \\
\hline \multirow{2}{*}{$\begin{array}{l}\text { Community funding and } \\
\text { support }\end{array}$} & SDR & 0.56 & \multirow{2}{*}{$\begin{array}{l}\text { Consumer health and } \\
\text { product impact }\end{array}$} & $\mathrm{CO} 2$ & 0.98 \\
\hline & SSN & 0.94 & & HCavg & 0.80 \\
\hline \multirow[b]{2}{*}{ Community involvement } & $\mathrm{CoC}$ & 0.34 & \multirow{12}{*}{$\begin{array}{l}\text { Product management and } \\
\text { consumer satisfaction }\end{array}$} & LT & 0.88 \\
\hline & VA & 0.74 & & & \\
\hline \multirow{2}{*}{ Corruption in business } & RofC & 0.99 & & $\mathrm{RC}_{\text {ratio }}$ & 0.57 \\
\hline & ACT & 0.96 & & & \\
\hline \multirow{3}{*}{ Fair business operations } & SPP & 0.83 & & REL & 0.99 \\
\hline & $\mathrm{ACB}$ & 0.95 & & & \\
\hline & $\mathrm{NCL}$ & 0.81 & & $\mathrm{TP}$ & 0.73 \\
\hline \multirow{5}{*}{ Stakeholder participation } & STCavg & 0.96 & & IQA & 0.94 \\
\hline & CFtot & 0.82 & & CR & 0.95 \\
\hline & CCtot & 0.48 & & II & 0.45 \\
\hline & ERIR & 0.63 & & \multirow[t]{2}{*}{$\mathrm{CP}$} & \multirow[t]{2}{*}{0.80} \\
\hline & EmpDM & 0.79 & & & \\
\hline
\end{tabular}

Source: Authors' results 


\section{CONCLUSION}

Current literature has proposed various ways for social sustainability assessment, however the lack of a clear definition of indicators and their quantitative characteristics still remains as an issue. This study aims to tackle these drawbacks and proposes a set of quantitative indicators suitable for social sustainability assessment of supply chains. Aspects covered by the indicators proposed in this work are focused on society and product responsibility.

Through literature review, a set of 24 indicators was identified and characterized with definition, relevance and equation. This characterization helps by providing relevant information for the monitoring social sustainability progress in supply chains. Furthermore, decision makers can benefit from the information obtained by this indicators in the process of designing and planning supply chains, as sustainability indicators are key tools that provide the basis for the decision-making process.

Validation of the proposed indicators has been performed through a content analysis, showing that the proposed indicators are suitable for the assessment of the whole supply chain. However, differences in the percentage of keywords occurrence can indicate that the relevance of the indicators depends on: (i) different echelon levels and (ii) different sectors. These conclusions further led to the development of a model for the assessment of the supply chains on 3 different levels. It means that there should exist three sets of indicators: (i) generic indicators suitable for the assessment of the whole supply chain regardless the product or service, (ii) echelon level indicators suitable for the assessment of social sustainability on echelon level, and (iii) specific indicators that are developed specifically for the assessment of particular industry sector.

Finally by performing one-way statistical analysis it was concluded that the echelon level doesn't influence the percentage of the keyword occurrence for proposed indicators. But also it can be concluded that some of the indicators are less relevant depending on the type of the industry. Thus future work should focus on the further analysis of impacts on indicator's importance. It means that thorough observation of sector specific indicators should be performed, as well as their further development. Also face-to-face in depth interviews should be performed so that better compatibility of proposed indicators with social sustainability assessment can be made. Further possibility of establishing real case study would enable calculation of the indicators and even better validation of indicators, and more importantly it would answer the questions on the indicators' relevance, data accessibility, etc.

\section{ACKNOWLEDGEMENT}

Authors would like to acknowledge financial support from Graduate School in Chemical Engineering (GSCE), Finland and project PTDC/AGR-FOR/2178/2014.

\section{REFERENCES}

Ahi, P., \& Searcy, C. (2015). An analysis of metrics used to measure performance in green and sustainable supply chains. Journal of Cleaner Production, 86, 360-377. doi: https://doi.org/10.1016/i.jclepro.2014.08.005

Ali, H. A. E. M., Al-Sulaihi, I. A., \& Al-Gahtani, K. S. (2013). Indicators for measuring performance of building constructions companies in Kingdom of Saudi Arabia. Journal of King Saud University - Engineering Sciences, 25, 125-134. doi: https://doi.org/10.1016/j.jksues.2012.03.002

Azapagic, A., \& Predan, S. (2000). Indicators of sustainable development for industry: A general framework. Trans IChemE, 78(B), 243-261. doi: https://doi.org/10.1205/095758200530763

Azcárate, F., Carrasco, F., \& Fernández, M. (2011). The role of integrated indicators in exhibiting business contribution to sustainable development: a survey of sustainability reporting initiatives. Revista de Contabilidad-Spanish Accounting Review, 14, 213-240. doi: https://doi.org/10.1016/S1138-4891(11)70033-4

Beske-Janssen, P., Johnson, M. P., \& Schaltegger, S. (2015). 20 years of performance measurement in sustainable supply chain management - what has been achieved? Supply Chain Management: An International Journal, 20(6), 664-680. doi: https://doi.org/10.1108/SCM-06-2015-0216

Bewick, V., L. Cheek, L., \& Ball, J. (2004). Statistics review 9: One-way analysis of variance. Critical Care, 8 (2), 130 136. doi: https://doi.org/10.1186/cc2836 
Borit, M., \& Santos, J. (2015). Getting traceability rights, from fish to advanced bio-technological products: a review of legislation. Journal of Cleaner Production, 104, 13-22. doi: https://doi.org/10.1016/i.jclepro.2015.05.003

Feng, S.C., \& Joung, C.B. (2009). An overview of proposed measurement infrastructure for sustainable manufacturing. The 7th Global Conference on Sustainable Manufacturing, December 2 - 4, 2009, Indian Institute of Technology Madras, Chennai, India, available at: https://www.nist.gov/node/620261 (accessed 11.10.2016).

Ferriss, A.L. (2010). Social Indicators Research Series 42: Approaches to Improving the Quality of Life. How to Enhance the Quality of Life. Springer, NY, USA. doi: https://doi.org/10.1007/978-90-481-9148-2

Flick, U. (2014). An Introduction to Qualitative Research. Sage Publications, CA, USA.

Fritz, M.M.C., Schöggl, J. -P., \& Baumgartner, R. J. (2017). Selected sustainability aspects for supply chain data exchange: Towards a supply chain-wide sustainability assessment. Journal of Cleaner Production, 141, 587-607. doi: https://doi.org/10.1016/j.jclepro.2016.09.080

Garcia, S., Y. Cintra, Y., Torres, R. de C. S. R., \& Lima, F. G. (2016). Corporate sustainability management: a proposed multi-criteria model to support balanced decision-making. Journal of Cleaner Production, 136(A), 181-196. doi: https://doi.org/10.1016/j.jclepro.2016.01.110

GRI (Global Reporting Initiative). (2011). Sustainability reporting guidelines. Amsterdam. The Netherlands.

Hák, T., S. Janoušková, S., \& Bedřich, M. (2016). Sustainable Development Goals: A need for relevant indicators. Ecological Indicators, 60, 565-573. doi: https://doi.org/10.1016/i.ecolind.2015.08.003

Hardoon, D., \& Heinrich, F. (2011). Bribe payers index. Transparency International, available at: http://www.transparency.org/bpi2011/results (accessed 15.01.2017)

Hassini, E., Surti, C., \& Searcy, C. (2012). A literature review and a case study of sustainable supply chains with a focus on metrics. Int. J. Production Economics, 140, 69-82. doi: https://doi.org/10.1016/i.ijpe.2012.01.042

Hsien, H.-F., \& Shannon, S. E. (2005). Three approaches to qualitative content analysis. Qualitative Health Research, 15(9), 1277-1288. doi: https://doi.org/10.1177/1049732305276687

Hutchins, M. J., \& Sutherland, J. W. (2008). An exploration of measures of social sustainability and their application to supply chain decisions. Journal of Cleaner Production, 16, 1688-1698. doi: https://doi.org/10.1016/j.jclepro.2008.06.001

Irawanto, D.W. (2015). Employee participation in decision-making: evidence from a state-owned enterprise in Indonesia. Management, 20(1), 159-172.

Kasemsap, K. (2016). Encouraging supply chain networks and customer loyalty in global supply chain. In Handbook of Research on Strategic Supply Chain Management in Retail Industry, edited by N. Kamath, N., \& S. Saurav, S. IGI Golbal, US. doi: https://doi.org/10.4018/978-1-4666-9894-9.ch006

Krippendorff, K. (2004). Reliability in content analysis: some common misconceptions and recommendations. Human Communication Research, 30(3), 411-433. doi: https://doi.org/10.1111/j.1468-2958.2004.tb00738.x/pdf

Labuschagne, C., Brent, A. C., \& van Erck, R. P. G. (2005). Assessing the sustainability performances of industries. Journal of Cleaner Production, 13, 373-385. doi: https://doi.org/10.1016/j.jclepro.2003.10.007

Lodhia, S., \& Martin, N. (2014). Corporate sustainability indicators: and Australian mining case study. Journal of Cleaner Production, 84, 107-115. doi: https://doi.org/10.1016/j.jclepro.2014.05.050

Mani, V., Agrawal, R., \& Sharma, V. (2014). Supplier selection using social sustainability: AHP based approach in India. International Strategic Management Review, 2, 98-112. doi: https://doi.org/10.1016/j.ism.2014.10.003

Mani, V., Agrawal, R., \& Sharma, V. (2015). Social sustainability in the supply chain: analysis of enablers. Management Research Review, 38(9), 1016-1042. doi: https://doi.org/10.1108/MRR-02-2014-0037

Mani, V., Agrawal, R., Gunasekaran, A., Papadopoulos, T., Dubey, R., \& Childe S. J. (2016). Social sustainability in the supply chain: Construct development and measurement validation. Ecological Indicators, 71, 270-279. doi: https://doi.org/10.1016/i.ecolind.2016.07.007

Mani, V., Gunasekaran, A., Papadopoulos, T., Hazan, B., \& Dubey, R. (2016). Supply chain social sustainability for developing nations: Evidence from India. Resources. Conservations and Recycling, 111, 42-52. doi: https://doi.org/10.1016/j.resconrec.2016.04.003

Martínez, J. C. V., \& Fransoo, J. C. (2017). Green Facility Location. In Sustainable Supply Chains. A Research-Based Textbook on Operations and Strategy, edited by Y. Bouchery et al. Springer International Publishing. doi: https://doi.org/10.1007/978-3-319-29791-0 9 
Meckenstock, J., Barbosa-Póvoa, A. P., \& Carvalho, A. (2015). The wicked character of sustainable supply chain management: evidence from sustainability reports. Business Strategy and the Environment, 25 (7), 449-477. doi: https://doi.org/10.1002/bse.1872

Mehralian, G., Rasekh, H.R., Akhavan, P., \& Ghatari, A. R. (2013). Prioritization of intellectual capital indicators in knowledge-based industries: Evidence from pharmaceutical industry. International Journal of Information Management, 33, 209-216. doi: https://doi.org/10.1016/j.ijinfomgt.2012.10.002

Missimer, M., Robèrt, K. -H., \& G. Broman, G. (2017). A strategic approach to social sustainability - Part 2: a principlebased definition. Journal of Cleaner Production, 140(1), 42-52. doi: https://doi.org/10.1016/j.jclepro.2016.04.059

Omri, A. E. (2009). Cooperation in supply chains: alliance formation and profit allocation among independent firms. Business administration, Ecole Centrale Paris, France.

Popovic, T., \& Kraslawski, A. (2015). Chapter 6: Social sustainability of complex systems. In: You, F. (Ed.) Sustainability of Products, Processes and Supply Chains. Theory and Applications: Elsevier. doi: https://doi.org/10.1016/B978-0-444-63472-6.00024-0

Potter, J. W. \& Levine-Donnerstein, D. (1999). Rethinking validity and reliability in content analysis. Journal of Applied Communication Research, 27, 258-284. doi: http://dx.doi.org/10.1080/00909889909365539

Prasad, B.D. (2008). Content analysis. A method in social science research. In Research methods for Social Work, edited by D. K. Lal Das, D.K., and \&V. Bhaskaran, V. New Delhi, Rawat.

Rahdary, A. H., \& Rostamy, A. A. A. (2015). Designing a general set of sustainability indicators at the corporate level. Journal of Cleaner Production, 108, 757-771. doi: https://doi.org/10.1016/i.jclepro.2015.05.108

Rametsteiner, E., Pülzl, H., J. Alkan-Olsson, J., \& Frederiksen, P. (2011). Sustainability indicator development - Science or political negotiation? Ecological Indicators, 11, 61-70. doi: https://doi.org/10.1016/j.ecolind.2009.06.009

Simões, M., Freitas, C. L., Barbosa-Póvoa, A. P., \& Carvalho, A. (2016). Social Life Cycle Assessment-A framework for midand end-point impact categories. Working-paper \#1-2016, CEG-IST, Instituto Superior Tècnico (Technical University of Lisbon), Portugal. Under review.

Spangenberg, J. H., \& Omann, I. (2006). Assessing social sustainability: social sustainability and its multicriteria assessment in sustainability scenario for Germany. International Journal of Innovation and Sustainable Development, 1(4), 318-348. doi: https://doi.org/10.1504/IJISD.2006.013734

Tahir, A. C., \& Darton, R. C. (2010). The process analysis method of selecting indicators to quantify the sustainability performance of business operations. Journal of Cleaner Production, 18, 1598-1607. doi: https://doi.org/10.1016/i.jclepro.2010.07.012

Vachon, S., \& Mao, Z. (2008). Linking supply chain strength to sustainable development: a country-level analysis. Journal of Cleaner Production, 16(15), 1552-1560. doi: https://doi.org/10.1016/j.jclepro.2008.04.012

Varsei, M., \& Polyakovskiy, S. (2017). Sustainable supply chain network design: A case of the wine industry in Australia. Omega, 66, 236-247. doi: https://doi.org/10.1016/j.omega.2015.11.009

Veleva, V., \& Ellenbecker, M. (2001). Indicators of sustainable production: framework and methodology. Journal of Cleaner Production, 9(6), 519-549. doi: https://doi.org/10.1016/S0959-6526(01)00010-5 


\section{APPENDIXES}

Table A1

List of sustainability reports used for content analysis

\begin{tabular}{|c|c|c|c|c|c|c|c|}
\hline Industry & Company & Year & Pages & $\begin{array}{l}\text { GRI } \\
\text { Version }\end{array}$ & Region & Country & $\begin{array}{l}\text { Generic } \\
\text { Echelon }\end{array}$ \\
\hline Mining & Agnico-Eagle Mines & 2011 & 109 & GRI3.1 & $\mathrm{NA}$ & $\mathrm{CA}$ & Upstream \\
\hline Mining & Anglo Platinum & 2011 & 172 & GRI3 & $\mathrm{AF}$ & $\mathrm{ZA}$ & Upstream \\
\hline Mining & AngloAmerican & 2011 & 82 & GRI3.1 & $\mathrm{EU}$ & UK & Upstream \\
\hline Mining & AngloGold Ashanti & 2011 & 64 & GRI3 & $\mathrm{AF}$ & $\mathrm{ZA}$ & Upstream \\
\hline Mining & $\begin{array}{l}\text { Barric Gold } \\
\text { Corporation }\end{array}$ & 2011 & 144 & GRI3 & $\mathrm{NA}$ & CA & Upstream \\
\hline Mining & BHP Billiton & 2011 & 54 & GRI3 & OC & $\mathrm{AU}$ & Upstream \\
\hline Mining & Codelco & 2011 & 84 & GRI3.1 & SA & CL & Upstream \\
\hline Mining & Freeport-McMoRan & 2011 & 36 & GRI3 & $\mathrm{NA}$ & US & Upstream \\
\hline Mining & Kinross & 2011 & 133 & GRI3 & NA & CA & Upstream \\
\hline Mining & Lonmin & 2011 & 81 & GRI3 & $\mathrm{EU}$ & UK & Upstream \\
\hline Mining & Teck & 2011 & 118 & GRI3 & NA & CA & Upstream \\
\hline Mining & Xstrata & 2011 & 68 & GRI3 & $\mathrm{EU}$ & $\mathrm{CH}$ & Upstream \\
\hline Oil and Gas & Amec & 2010 & 53 & GRI3 & $\mathrm{EU}$ & UK & Upstream \\
\hline Oil and Gas & BG Group & 2010 & 42 & GRI3 & $\mathrm{EU}$ & UK & Upstream \\
\hline Oil and Gas & ENI & 2010 & 36 & GRI3 & $\mathrm{EU}$ & IT & Upstream \\
\hline Oil and Gas & Nexen & 2010 & 28 & GRI3 & NA & CA & Upstream \\
\hline Oil and Gas & Repsol & 2010 & 115 & GRI3 & $\mathrm{EU}$ & ES & Upstream \\
\hline Oil and Gas & S-OIL & 2010 & 74 & GRI3 & AS & $\mathrm{KR}$ & Upstream \\
\hline Oil and Gas & Saipem & 2011 & 84 & GRI3 & EU & IT & Upstream \\
\hline Oil and Gas & Santos & 2011 & 62 & GRI3.1 & $\mathrm{OC}$ & $\mathrm{AU}$ & Upstream \\
\hline Oil and Gas & Sasol & 2011 & 69 & GRI3.1 & $\mathrm{AF}$ & $\mathrm{ZA}$ & Upstream \\
\hline Oil and Gas & SBM Offshore & 2010 & 118 & GRI3 & $\overline{E U}$ & $\mathrm{NL}$ & Upstream \\
\hline Oil and Gas & Suncor & 2011 & 26 & GRI3 & $\mathrm{NA}$ & $\mathrm{CA}$ & Upstream \\
\hline Oil and Gas & Total & 2010 & 80 & GRI3 & $\mathrm{EU}$ & FR & Upstream \\
\hline Oil and Gas & $\begin{array}{l}\text { Woodside } \\
\text { Petroleum }\end{array}$ & 2011 & 39 & GRI3 & OC & $\mathrm{AU}$ & Upstream \\
\hline
\end{tabular}




\begin{tabular}{|c|c|c|c|c|c|c|c|}
\hline Materials & $\mathrm{CRH}$ & 2010 & 84 & GRI3 & $\mathrm{EU}$ & $\mathrm{IE}$ & Upstream \\
\hline Materials & Dow Chemical & 2010 & 94 & GRI3 & $\mathrm{NA}$ & US & Upstream \\
\hline Materials & Holcim & 2009 & 40 & GRI3 & $\mathrm{EU}$ & $\mathrm{CH}$ & Upstream \\
\hline Materials & Italcementi Group & 2010 & 72 & GRI3 & $\mathrm{EU}$ & IT & Upstream \\
\hline Materials & Lafarge & 2010 & 44 & GRI3 & EU & FR & Upstream \\
\hline Materials & Linde & 2010 & 116 & GRI3.1 & EU & $\mathrm{DE}$ & Upstream \\
\hline Materials & Praxair & 2010 & 79 & GRI3 & NA & US & Upstream \\
\hline Materials & SCG & 2010 & 108 & GRI3 & AS & $\mathrm{TH}$ & Upstream \\
\hline Utilities & AGL Energy & 2011 & 105 & GRI3 & $\mathrm{OC}$ & $\mathrm{AU}$ & Upstream \\
\hline Utilities & Duke Energy & 2011 & 36 & GRI3 & $\mathrm{NA}$ & US & Upstream \\
\hline Utilities & E.ON & 2011 & 129 & GRI3 & $\mathrm{EU}$ & $\mathrm{DE}$ & Upstream \\
\hline Utilities & Exelon & 2011 & 114 & GRI3.1 & $\mathrm{NA}$ & US & Upstream \\
\hline Utilities & Fortum & 2011 & 124 & GRI3.1 & $\mathrm{EU}$ & FI & Upstream \\
\hline Utilities & Iberdrola & 2011 & 255 & GRI3.1 & $\mathrm{EU}$ & ES & Upstream \\
\hline Utilities & PG\&E & 2011 & 224 & GRI3 & NA & US & Upstream \\
\hline Utilities & Red Electrica & 2011 & 184 & GRI3.1 & $\mathrm{EU}$ & ES & Upstream \\
\hline Utilities & RWE & 2011 & 142 & GRI3 & $\mathrm{EU}$ & $\mathrm{DE}$ & Upstream \\
\hline Utilities & Sempra Energy & 2011 & 70 & GRI3.1 & $\mathrm{NA}$ & US & Upstream \\
\hline Utilities & Snam & 2011 & 102 & GRI3.1 & $\mathrm{EU}$ & IT & Upstream \\
\hline Utilities & Spectra Energy & 2011 & 30 & GRI3.1 & $\mathrm{NA}$ & US & Upstream \\
\hline Utilities & Terna & 2011 & 220 & GRI3.1 & $\mathrm{EU}$ & IT & Upstream \\
\hline Industrials & $3 \mathrm{M}$ & 2011 & 107 & GRI3.1 & $\mathrm{NA}$ & US & Midstream \\
\hline Industrials & Atlas Copco & 2011 & 28 & GRI3 & $\mathrm{EU}$ & SE & Midstream \\
\hline Industrials & Bombardier & 2010 & 169 & GRI3 & $\mathrm{NA}$ & $\mathrm{CA}$ & Midstream \\
\hline Industrials & Daikin & 2011 & 32 & GRI3 & AS & $\mathrm{JP}$ & Midstream \\
\hline Industrials & Finmeccanica & 2010 & 160 & GRI3 & EU & IT & Midstream \\
\hline Industrials & General Electric & 2011 & 42 & GRI3 & $\mathrm{NA}$ & US & Midstream \\
\hline Industrials & $\begin{array}{l}\text { Hyundai } \\
\text { Engineering \& } \\
\text { Construction }\end{array}$ & 2010 & 75 & GRI3.1 & AS & KR & Midstream \\
\hline Industrials & Ingersoll Rand & 2011 & 75 & GRI3.1 & $\mathrm{NA}$ & US & Midstream \\
\hline Industrials & Komatsu & 2011 & 52 & GRI3.1 & AS & $\mathrm{JP}$ & Midstream \\
\hline
\end{tabular}




\begin{tabular}{|c|c|c|c|c|c|c|c|}
\hline Industrials & Metso & 2011 & 57 & GRI3.1 & $\mathrm{EU}$ & FI & Midstream \\
\hline Industrials & Sandvik & 2011 & 13 & GRI3 & EU & SE & Midstream \\
\hline Industrials & Siemens & 2011 & 90 & GRI3 & $\mathrm{EU}$ & $\mathrm{DE}$ & Midstream \\
\hline Industrials & STX Engine & 2011 & 71 & GRI3.1 & AS & $\mathrm{KR}$ & Midstream \\
\hline Industrials & Sulzer & 2011 & 16 & GRI3 & EU & $\mathrm{CH}$ & Midstream \\
\hline Industrials & Toshiba & 2011 & 60 & GRI3 & AS & JP & Midstream \\
\hline Industrials & Volvo Group & 2011 & 101 & GRI3 & EU & SE & Midstream \\
\hline $\begin{array}{l}\text { Consumer } \\
\text { Goods }\end{array}$ & Avon & 2011 & 157 & GRI3 & NA & US & Midstream \\
\hline $\begin{array}{l}\text { Consumer } \\
\text { Goods }\end{array}$ & $\begin{array}{l}\text { Campbell Soup } \\
\text { Company }\end{array}$ & 2011 & 122 & GRI3 & NA & US & Midstream \\
\hline $\begin{array}{l}\text { Consumer } \\
\text { Goods }\end{array}$ & Coca-Cola Company & 2011 & 95 & GRI3.1 & NA & US & Midstream \\
\hline $\begin{array}{l}\text { Consumer } \\
\text { Goods }\end{array}$ & Danisco & 2011 & 94 & GRI3 & EU & DK & Midstream \\
\hline $\begin{array}{l}\text { Consumer } \\
\text { Goods }\end{array}$ & Diageo & 2011 & 96 & GRI3 & $\mathrm{EU}$ & UK & Midstream \\
\hline $\begin{array}{l}\text { Consumer } \\
\text { Goods }\end{array}$ & Estée Lauder & 2010 & 54 & GRI3 & NA & US & Midstream \\
\hline $\begin{array}{l}\text { Consumer } \\
\text { Goods }\end{array}$ & Fujifilm & 2011 & 74 & GRI3 & AS & JP & Midstream \\
\hline $\begin{array}{l}\text { Consumer } \\
\text { Goods }\end{array}$ & Henkel & 2011 & 50 & GRI3 & $\mathrm{EU}$ & $\mathrm{DE}$ & Midstream \\
\hline $\begin{array}{l}\text { Consumer } \\
\text { Goods }\end{array}$ & Kao & 2011 & 131 & GRI3 & AS & JP & Midstream \\
\hline $\begin{array}{l}\text { Consumer } \\
\text { Goods }\end{array}$ & Kimberly-Clark & 2011 & 141 & GRI3 & NA & US & Midstream \\
\hline $\begin{array}{l}\text { Consumer } \\
\text { Goods }\end{array}$ & Néstle & 2011 & 295 & GRI3.1 & EU & $\mathrm{CH}$ & Midstream \\
\hline $\begin{array}{l}\text { Consumer } \\
\text { Goods }\end{array}$ & Procter\&Gamble & 2011 & 76 & GRI3 & NA & US & Midstream \\
\hline $\begin{array}{l}\text { Consumer } \\
\text { Goods }\end{array}$ & Sara Lee & 2011 & 68 & GRI3.1 & NA & US & Midstream \\
\hline $\begin{array}{l}\text { Consumer } \\
\text { Goods }\end{array}$ & SCA & 2011 & 78 & GRI3 & EU & SE & Midstream \\
\hline $\begin{array}{l}\text { Consumer } \\
\text { Goods }\end{array}$ & Unilever & 2011 & 44 & GRI3 & $\mathrm{EU}$ & NL & Midstream \\
\hline
\end{tabular}




\begin{tabular}{|c|c|c|c|c|c|c|c|}
\hline Electronics & AU Optronics & 2011 & 81 & GRI3.1 & AS & TW & Midstream \\
\hline Electronics & NEC & 2011 & 28 & GRI3.1 & AS & JP & Midstream \\
\hline Electronics & Fujitsu & 2010 & 100 & GRI3.1 & AS & JP & Midstream \\
\hline Electronics & Hewlett Packard & 2011 & 186 & GRI3 & $\mathrm{NA}$ & US & Midstream \\
\hline Electronics & Epson & 2011 & 70 & GRI3.1 & AS & JP & Midstream \\
\hline Electronics & TDK & 2011 & 29 & GRI3 & AS & JP & Midstream \\
\hline Electronics & Panasonic & 2011 & 84 & GRI3.1 & AS & $J P$ & Midstream \\
\hline Electronics & LG Electronics & 2011 & 90 & GRI3.1 & AS & KR & Midstream \\
\hline Electronics & Intel & 2011 & 133 & GRI3.1 & NA & US & Midstream \\
\hline Electronics & SK hynix & 2011 & 102 & GRI3.1 & AS & $\mathrm{KR}$ & Midstream \\
\hline Electronics & STMicroelectronics & 2011 & 72 & GRI3 & EU & $\mathrm{CH}$ & Midstream \\
\hline Electronics & Konica Minolta & 2011 & 44 & GRI3 & AS & $\mathrm{JP}$ & Midstream \\
\hline Automotive & BMW & 2010 & 120 & GRI3 & $\mathrm{EU}$ & $\mathrm{DE}$ & Midstream \\
\hline Automotive & Daimler & 2011 & 120 & GRI3.1 & $\mathrm{EU}$ & $\overline{\mathrm{DE}}$ & Midstream \\
\hline Automotive & Denso & 2011 & 92 & GRI3 & AS & JP & Midstream \\
\hline Automotive & Fiat & 2011 & 268 & GRI3.1 & $\mathrm{EU}$ & IT & Midstream \\
\hline Automotive & Hyundai Motor & 2010 & 86 & GRI3 & $\mathrm{AD}$ & $\mathrm{KR}$ & Midstream \\
\hline Automotive & Johnson Controls & 2011 & 241 & GRI3.1 & $\mathrm{NA}$ & US & Midstream \\
\hline Automotive & Mazda & 2011 & 139 & GRI3.1 & AS & JP & Midstream \\
\hline Automotive & Nissan & 2011 & 88 & GRI3.1 & AS & JP & Midstream \\
\hline Automotive & Pirelli & 2011 & 161 & GRI3.1 & $\mathrm{EU}$ & IT & Midstream \\
\hline Automotive & Volkswagen & 2011 & 104 & GRI3 & EU & $\mathrm{DE}$ & Midstream \\
\hline $\begin{array}{l}\text { Transport and } \\
\text { Logistics }\end{array}$ & Abertis & 2011 & 105 & GRI3.1 & $\overline{E U}$ & ES & Downstream \\
\hline $\begin{array}{l}\text { Transport and } \\
\text { Logistics }\end{array}$ & Air France-KLM & 2011 & 80 & GRI3.1 & $\mathrm{EU}$ & FR & Downstream \\
\hline $\begin{array}{l}\text { Transport and } \\
\text { Logistics }\end{array}$ & Ball & 2011 & 30 & GRI3.1 & NA & US & Downstream \\
\hline $\begin{array}{l}\text { Transport and } \\
\text { Logistics }\end{array}$ & $\begin{array}{l}\text { Cathay Pacific } \\
\text { Airways }\end{array}$ & 2011 & 154 & GRI3.1 & AS & $\mathrm{CN}$ & Downstream \\
\hline $\begin{array}{l}\text { Transport and } \\
\text { Logistics }\end{array}$ & Deutsche Post DHL & 2011 & 88 & GRI3 & EU & $\mathrm{DE}$ & Downstream \\
\hline
\end{tabular}




\begin{tabular}{|c|c|c|c|c|c|c|c|}
\hline $\begin{array}{l}\text { Transport and } \\
\text { Logistics }\end{array}$ & Fraport & 2011 & 49 & GRI3.1 & $\mathrm{EU}$ & $\mathrm{DE}$ & Downstream \\
\hline $\begin{array}{l}\text { Transport and } \\
\text { Logistics }\end{array}$ & Maersk & 2011 & 82 & GRI3 & $\overline{\mathrm{EU}}$ & DK & Downstream \\
\hline $\begin{array}{l}\text { Transport and } \\
\text { Logistics }\end{array}$ & $\begin{array}{l}\text { Nippon Yusen } \\
\text { Kaisha }\end{array}$ & 2011 & 52 & GRI3.1 & AS & JP & Downstream \\
\hline $\begin{array}{l}\text { Transport and } \\
\text { Logistics }\end{array}$ & Transurban & 2011 & 40 & GRI3 & $\mathrm{OC}$ & $\mathrm{AU}$ & Downstream \\
\hline $\begin{array}{l}\text { Transport and } \\
\text { Logistics }\end{array}$ & $\begin{array}{l}\text { United Parcel } \\
\text { Service }\end{array}$ & 2011 & 149 & GRI3.1 & NA & US & Downstream \\
\hline Retail & Ahold & 2011 & 76 & GRI3 & $\mathrm{EU}$ & NL & Downstream \\
\hline Retail & Hennes \& Mauritz & 2011 & 89 & GRI3 & $\mathrm{EU}$ & SE & Downstream \\
\hline Retail & Kesko & 2010 & 94 & GRI3 & $\overline{E U}$ & FI & Downstream \\
\hline Retail & Kingfisher & 2010 & 111 & GRI3.1 & $\overline{E U}$ & UK & Downstream \\
\hline Retail & Lotte Shopping & 2010 & 120 & GRI3 & AS & KR & Downstream \\
\hline Retail & Marks \& Spencer & 2010 & 56 & GRI3.1 & $\overline{E U}$ & UK & Downstream \\
\hline Retail & Office Depot & 2010 & 24 & GRI3 & $\mathrm{NA}$ & $\mathrm{CA}$ & Downstream \\
\hline Retail & Staples & 2010 & 91 & GRI3 & NA & US & Downstream \\
\hline Retail & Wesfarmers & 2011 & 76 & GRI3 & $\mathrm{OC}$ & $\mathrm{AU}$ & Downstream \\
\hline $\begin{array}{l}\text { Telecommunicat } \\
\text { ions }\end{array}$ & BT Group & 2011 & 255 & GRI3.1 & $\overline{E U}$ & UK & Downstream \\
\hline $\begin{array}{l}\text { Telecommunicat } \\
\text { ions }\end{array}$ & $\begin{array}{l}\text { France Telecom- } \\
\text { Orange }\end{array}$ & 2011 & 160 & GRI3 & $\mathrm{EU}$ & FR & Downstream \\
\hline $\begin{array}{l}\text { Telecommunicat } \\
\text { ions }\end{array}$ & $\mathrm{KPN}$ & 2011 & 72 & GRI3.1 & $\mathrm{EU}$ & NL & Downstream \\
\hline $\begin{array}{l}\text { Telecommunicat } \\
\text { ions }\end{array}$ & $\mathrm{K}^{\prime} \mathrm{T}$ & 2011 & 54 & GRI3.1 & $\mathrm{AD}$ & $\mathrm{KR}$ & Downstream \\
\hline $\begin{array}{l}\text { Telecommunicat } \\
\text { ions }\end{array}$ & Portugal Telecom & 2011 & 165 & GRI3.1 & $\overline{E U}$ & PT & Downstream \\
\hline $\begin{array}{l}\text { Telecommunicat } \\
\text { ions }\end{array}$ & SK Telecom & 2011 & 64 & GRI3.1 & $\mathrm{AD}$ & $\mathrm{KR}$ & Downstream \\
\hline $\begin{array}{l}\text { Telecommunicat } \\
\text { ions }\end{array}$ & Telecom Italia & 2011 & 144 & GRI3.1 & $\mathrm{EU}$ & IT & Downstream \\
\hline $\begin{array}{l}\text { Telecommunicat } \\
\text { ions }\end{array}$ & Telefónica & 2011 & 90 & GRI3.1 & $\overline{\mathrm{EU}}$ & ES & Downstream \\
\hline $\begin{array}{l}\text { Telecommunicat } \\
\text { ions }\end{array}$ & Telenor & 2011 & 43 & GRI3.1 & $\overline{\mathrm{EU}}$ & $\mathrm{NO}$ & Downstream \\
\hline
\end{tabular}




\begin{tabular}{|c|c|c|c|c|c|c|c|}
\hline $\begin{array}{l}\text { Telecommunicat } \\
\text { ions }\end{array}$ & TeliaSonera & 2011 & 45 & GRI3.1 & $\mathrm{EU}$ & SE & Downstream \\
\hline $\begin{array}{l}\text { Telecommunicat } \\
\text { ions }\end{array}$ & Telstra & 2011 & 79 & GRI3 & $\mathrm{OC}$ & $\mathrm{AU}$ & Downstream \\
\hline $\begin{array}{l}\text { Telecommunicat } \\
\text { ions }\end{array}$ & Vodafone Group & 2011 & 24 & GRI3 & $\mathrm{EU}$ & UK & Downstream \\
\hline Financials & $\begin{array}{l}\text { Banca Monte dei } \\
\text { Paschi di Siena }\end{array}$ & 2010 & 120 & GRI3 & $\overline{\mathrm{EU}}$ & IT & Downstream \\
\hline Financials & Barclays & 2010 & 103 & GRI3 & $\mathrm{EU}$ & UK & Downstream \\
\hline Financials & Bradesco & 2010 & 60 & GRI3 & $\mathrm{SA}$ & $\mathrm{BR}$ & Downstream \\
\hline Financials & CIBC & 2011 & 85 & GRI3 & NA & $\mathrm{CA}$ & Downstream \\
\hline Financials & Dexia & 2010 & 48 & GRI3 & $\overline{\mathrm{EU}}$ & $\mathrm{BE}$ & Downstream \\
\hline Financials & DnB NOR & 2009 & 32 & GRI3 & $\mathrm{EU}$ & $\mathrm{NO}$ & Downstream \\
\hline Financials & Intesa Sanpaolo & 2010 & 120 & GRI3 & $\mathrm{EU}$ & IT & Downstream \\
\hline Financials & Nedbank Group & 2009 & 96 & GRI3 & $\mathrm{AF}$ & $\mathrm{ZA}$ & Downstream \\
\hline Financials & $\begin{array}{l}\text { Royal Bank of } \\
\text { Canada }\end{array}$ & 2011 & 131 & GRI3 & NA & $\mathrm{CA}$ & Downstream \\
\hline Financials & $\begin{array}{l}\text { Royal Bank of } \\
\text { Scotland }\end{array}$ & 2010 & 44 & GRI3 & $\mathrm{EU}$ & UK & Downstream \\
\hline Financials & Westpac Group & 2011 & 44 & GRI3 & $\mathrm{OC}$ & $\mathrm{AU}$ & Downstream \\
\hline TOTAL & 141 companies & & $\begin{array}{l}\text { 13148 } \\
\text { pgs. }\end{array}$ & & & $\begin{array}{l}25 \\
\text { countries }\end{array}$ & \\
\hline
\end{tabular}

Source: Companies' GRI reports 
Keywords defined for content analysis

\begin{tabular}{|c|c|c|c|}
\hline Mid-point & \multicolumn{2}{|l|}{ Indicator } & Keywords \\
\hline \multirow[t]{2}{*}{$\begin{array}{l}\text { Community funding and } \\
\text { support }\end{array}$} & SSN & Satisfaction of social needs & $\begin{array}{l}\text { Social contribution; } \\
\text { contribution to community; } \\
\text { community contribution }\end{array}$ \\
\hline & SDR & Share of distributed revenues & $\begin{array}{l}\text { Community investments; } \\
\text { community programme }\end{array}$ \\
\hline \multirow[t]{2}{*}{ Community involvement } & $\mathrm{CoC}$ & Community complains & (community) complains \\
\hline & VA & Volunteering activities & Volunteering (in community) \\
\hline \multirow[t]{2}{*}{ Corruption in business } & RofC & Risk of corruption & Corruption \\
\hline & ACT & $\begin{array}{l}\text { Employees trained for anti- } \\
\text { corruption }\end{array}$ & Anti-corruption \\
\hline \multirow[t]{3}{*}{ Fair business operations } & SPP & Support for political parties & $\begin{array}{l}\text { Political support; political } \\
\text { party }\end{array}$ \\
\hline & ACB & Anti-competitive behaviour & $\begin{array}{l}\text { Anti-competitive; anti-trust; } \\
\text { monopoly }\end{array}$ \\
\hline & NCL & $\begin{array}{l}\text { Sanctions for non-compliance } \\
\text { with law }\end{array}$ & Compliance with law \\
\hline \multirow[t]{5}{*}{ Stakeholder participation } & STC $_{\text {avg }}$ & Strategic cooperation & Alliances; licensing \\
\hline & $\mathrm{CF}_{\text {tot }}$ & Community forums & Forum \\
\hline & $\mathrm{CC}_{\text {tot }}$ & Complaint channels & Channel \\
\hline & ERIR & $\begin{array}{l}\text { Effectiveness in response to } \\
\text { information request }\end{array}$ & $\begin{array}{l}\text { Information request; request } \\
\text { for information }\end{array}$ \\
\hline & EmpDM & $\begin{array}{l}\text { Employment involvement in } \\
\text { decision making }\end{array}$ & $\begin{array}{l}\text { Employee engagement; } \\
\text { employee involvement; } \\
\text { engagement of employee }\end{array}$ \\
\hline \multirow[t]{2}{*}{ Consumer health and safety } & $\mathrm{CO} 2$ & $\mathrm{CO}_{2}$ emission & $\mathrm{CO}_{2}$; carbon-dioxide \\
\hline & $\mathrm{HC}_{\text {avg }}$ & Health complains & (customer) complains \\
\hline \multirow{5}{*}{$\begin{array}{l}\text { Product management and } \\
\text { consumer satisfaction }\end{array}$} & LT & Lead time & Customer needs \\
\hline & $\mathrm{RC}_{\text {ratio }}$ & Percentage of repeated customers & $\begin{array}{l}\text { Customer satisfaction; } \\
\text { company performance }\end{array}$ \\
\hline & REL & Average period of relationship & Relationship \\
\hline & TP & Traceability of product & Traceability \\
\hline & IQA & Inspection and quality audits & Quality audits \\
\hline
\end{tabular}




\begin{tabular}{|l|l|l|l|}
\hline \multirow{2}{*}{} & CR & Compliance with regulations & Advertising \\
\cline { 2 - 4 } & II & Information infringement & Copyright \\
\cline { 2 - 4 } & CP & Customer privacy & Customer privacy \\
\hline
\end{tabular}

Source: Authors' database 